\section{Parasitology}

\section{cambridge.org/par}

\section{Review}

Cite this article: Banerjee $\mathrm{N}$, Hallem EA (2020). The role of carbon dioxide in nematode behaviour and physiology. Parasitology 147, 841-854. https://doi.org/10.1017/ S0031182019001422

Received: 11 July 2019

Revised: 4 September 2019

Accepted: 16 September 2019

First published online: 11 October 2019

\section{Key words:}

Carbon dioxide; chemotaxis; C. elegans; hookworms; nematodes; parasitic nematodes; sensory behaviour; Strongyloides

\section{Author for correspondence:}

Elissa A. Hallem, E-mail: ehallem@ucla.edu

\title{
The role of carbon dioxide in nematode behaviour and physiology
}

\author{
Navonil Banerjee and Elissa A. Hallem (D
}

Department of Microbiology, Immunology, and Molecular Genetics, University of California, Los Angeles, CA, USA

\begin{abstract}
Carbon dioxide $\left(\mathrm{CO}_{2}\right)$ is an important sensory cue for many animals, including both parasitic and free-living nematodes. Many nematodes show context-dependent, experience-dependent and/or life-stage-dependent behavioural responses to $\mathrm{CO}_{2}$, suggesting that $\mathrm{CO}_{2}$ plays crucial roles throughout the nematode life cycle in multiple ethological contexts. Nematodes also show a wide range of physiological responses to $\mathrm{CO}_{2}$. Here, we review the diverse responses of parasitic and free-living nematodes to $\mathrm{CO}_{2}$. We also discuss the molecular, cellular and neural circuit mechanisms that mediate $\mathrm{CO}_{2}$ detection in nematodes, and that drive context-dependent and experience-dependent responses of nematodes to $\mathrm{CO}_{2}$.
\end{abstract}

\section{Introduction}

Carbon dioxide $\left(\mathrm{CO}_{2}\right)$ is an important sensory cue for animals across diverse phyla, including Nematoda (Lahiri and Forster, 2003; Shusterman and Avila, 2003; Bensafi et al., 2007; Smallegange et al., 2011; Carrillo and Hallem, 2015). While the $\mathrm{CO}_{2}$ concentration in ambient air is approximately $0.038 \%$ (Scott, 2011), many nematodes encounter much higher levels of $\mathrm{CO}_{2}$ in their microenvironment during the course of their life cycles. For instance, parasitic nematodes may encounter high $\mathrm{CO}_{2}$ concentrations released from potential hosts as a byproduct of respiration or from the host feces within which they develop (Byrnes et al., 1997; Buszewski et al., 2007; Carrillo and Hallem, 2015). $\mathrm{CO}_{2}$ concentrations are also high in specific tissues such as the venous bloodstream, lungs and intestine (Jensen and Jorgensen, 1994; Rotbart et al., 2017), suggesting $\mathrm{CO}_{2}$ may be an important intra-host cue for parasitic nematodes (Hawdon and Schad, 1990; Bekelaar et al., 2018, 2019). Moreover, many free-living nematodes are found in rotting vegetation, where $\mathrm{CO}_{2}$ levels are often high (Burg and Burg, 1965; Felix and Duveau, 2012). Therefore, nematodes must detect and respond appropriately to elevated $\mathrm{CO}_{2}$ concentrations to survive, navigate through their microenvironment and propagate.

$\mathrm{CO}_{2}$ may serve as a beneficial or detrimental cue for nematodes depending on specific circumstances (Carrillo and Hallem, 2015). For instance, in the case of parasitic nematodes, $\mathrm{CO}_{2}$ may be necessary to promote parasite-host interactions and thus support their parasitic life cycle. For free-living nematodes, high $\mathrm{CO}_{2}$ levels present in their natural habitats may act as signals for food, predators, pathogens or conspecifics (Carrillo and Hallem, 2015). Because $\mathrm{CO}_{2}$ is a complex cue that can have either a positive or negative valence, it is not surprising that different species of nematodes have developed distinct behavioural and physiological responses to $\mathrm{CO}_{2}$. Moreover, many species, both free-living and parasitic, exhibit $\mathrm{CO}_{2}$ responses that vary with context, previous experience and/or life stage. Recent studies of the free-living model nematode Caenorhabditis elegans have provided insight into the cellular and molecular mechanisms that drive and modulate $\mathrm{CO}_{2}$-evoked responses. In contrast, the mechanisms that promote the diverse responses of parasitic nematodes to $\mathrm{CO}_{2}$ have not yet been elucidated due to the historic lack of tools required for molecular genetic studies of these worms. However, as a result of recent developments in molecular genetic techniques, we are now in a position to interrogate the neural circuits and molecular signals that promote $\mathrm{CO}_{2}$ responses in parasitic nematodes. The findings from these studies will enhance our understanding of the role of $\mathrm{CO}_{2}$ in sculpting parasite-host interactions and may enable the development of novel strategies to combat harmful nematode infections. Here, we review our existing knowledge of how various nematode species respond behaviourally and physiologically to $\mathrm{CO}_{2}$. We also discuss how $\mathrm{CO}_{2}$ responsiveness can be modulated based on context, previous experience and life stage.

\section{Responses of mammalian-parasitic nematodes to $\mathrm{CO}_{2}$}

\section{Introduction to parasitic nematodes of mammals}

Mammalian-parasitic nematodes infect over a billion people worldwide and are a major cause of morbidity in low-resource areas (Boatin et al., 2012). Infections with soil-transmitted nematodes can cause chronic gastrointestinal distress, stunted growth and cognitive impairment in children, anaemia and even fatality in infants and immunocompromised individuals (Lustigman et al., 2012). Infections with vector-transmitted nematodes can cause severe symptoms such as permanent disfigurement and blindness (Lustigman et al., 2012). Additionally, 
parasitic nematodes that infect livestock are an enormous source of economic burden (Jasmer et al., 2003). Current treatments for infections depend on anthelminthic drugs that reduce the worm burden in heavier infections but do not prevent reinfections, with the result that reinfection is common in endemic areas (Prichard et al., 2012). In addition, drug resistance resulting from mass drug administration is a major challenge for the treatment of nematode-infected livestock (Kumar et al., 2013; Roeber et al., 2013; Emery et al., 2016; Learmount et al., 2016) and is expected to be a concern for the treatment of nematode-infected humans in the near future (Keiser and Utzinger, 2008; Diawara et al., 2013; Repetto et al., 2018). The drugs currently available are also not sufficient to eliminate human infections in all cases, at least by following the administration schedules under practice (Repetto et al., 2018).

Many of these nematodes are gastrointestinal parasites with a developmentally arrested infective larval stage that inhabits the environment and infects hosts following either skin penetration or passive ingestion, depending on the species (Gang and Hallem, 2016; Bryant and Hallem, 2018). The infective larval stages of these species respond robustly to a diverse array of host and environmental sensory cues, including $\mathrm{CO}_{2}$ (Gang and Hallem, 2016; Bryant and Hallem, 2018). In addition, many parasitic nematodes may rely on sensory cues inside the host body, including $\mathrm{CO}_{2}$, to re-initiate development upon host entry, direct somatic migration and establish a successful infection (Hawdon and Schad, 1990, 1992; Hawdon et al., 1992; Bekelaar et al., 2018, 2019).

\section{Responses of skin-penetrating nematodes to $\mathrm{CO}_{2}$}

Skin-penetrating nematodes such as the human-parasitic hookworms Ancylostoma duodenale and Necator americanus and the human-parasitic threadworm Strongyloides stercoralis are gastrointestinal parasites that infect hosts as developmentally arrested third-stage larvae (iL3s) (Roberts et al., 2005; Nutman, 2017; Velikkakam et al., 2017). The iL3s are soil-dwelling and actively engage in host seeking using a variety of host-associated sensory cues (Gang and Hallem, 2016; Bryant and Hallem, 2018). These parasites generally have narrow host ranges, infecting only a limited number of host species (Haley, 1961; Bezubik, 1965; Nolan et al., 2007; Viney and Lok, 2007; Viney and Kikuchi, 2017). After invading a host by skin penetration, the iL3s resume development inside the host, a process called activation (Stoltzfus et al., 2012 , 2014). The nematodes then migrate through the host body to their final destination, the small intestine, where they reside as parasitic adults (Roberts et al., 2005; Nutman, 2017; Velikkakam et al., 2017). The adults reproduce in the small intestine, and then the eggs or young larvae, depending on the species, exit the host body in feces. The nematodes inhabit the feces until they develop into iL3s (Roberts et al., 2005; Nutman, 2017; Velikkakam et al., 2017). In most species, all of the progeny of the parasitic adults develop directly into iL3s. However, Strongyloides species can cycle through one or a limited number of free-living generations on the feces before developmentally arresting as iL3s (Roberts et al., 2005). Strongyloides stercoralis can also pass through multiple generations inside the same host through autoinfective cycles (Roberts et al., 2005).

Many skin-penetrating nematodes show behavioural responses to $\mathrm{CO}_{2}$. For example, iL3s of the dog hookworm Ancylostoma caninum display increased nictation in the presence of $\mathrm{CO}_{2}$ (Granzer and Haas, 1991). Nictation is a specialized behaviour displayed by many parasitic nematodes in which the worm stands on its tail and waves its head in the air to facilitate attachment to mobile hosts (Granzer and Haas, 1991; Bryant and Hallem, 2018). In addition, both Ancylostoma caninum and Strongyloides stercoralis iL3s exhibit increased movement when exposed to human breath, and this behaviour is not observed when $\mathrm{CO}_{2}$ is removed from the breath (Sciacca et al., 2002). Similarly, the human-parasitic hookworms Ancylostoma duodenale and Necator americanus display increased activity in response to $\mathrm{CO}_{2}$ in combination with heat and/or moisture (Haas et al., 2005). The similar responses of Strongyloides stercoralis and hookworms to $\mathrm{CO}_{2}$ is particularly notable given their phylogenetic divergence, with Strongyloides stercoralis in clade IV and hookworms in clade V (Blaxter and Koutsovoulos, 2015; Blaxter et al., 2016). However, these studies did not look at migration in $\mathrm{CO}_{2}$ gradients, and whether $\mathrm{CO}_{2}$ was an attractant or repellent was not clear.

More recent studies demonstrated that skin-penetrating iL3s of the human parasites Strongyloides stercoralis and Ancylostoma ceylanicum and the rat parasites Strongyloides ratti and Nippostrongylus brasiliensis are repelled by $\mathrm{CO}_{2}$ in $\mathrm{CO}_{2}$-chemotaxis assays (Fig. 1A, B) (Castelletto et al., 2014; Ruiz et al., 2017). A lack of attraction towards $\mathrm{CO}_{2}$ is consistent with the route of infection of skin-penetrating nematodes, since mammalian skin surfaces emit low concentrations of $\mathrm{CO}_{2}$ (Alkalay et al., 1971). On the other hand, fecal deposits contain high levels of $\mathrm{CO}_{2}$ resulting from aerobic respiration of fecal bacteria (Jensen and Jorgensen, 1994; de Lacy Costello et al., 2014; Rotbart et al., 2017), and $\mathrm{CO}_{2}$ repulsion may drive these iL3s off of host feces and into the environment in search of new hosts.

\section{Responses of passively ingested nematodes to $\mathrm{CO}_{2}$}

Many passively ingested gastrointestinal nematodes have a motile environmental iL3 stage that invades hosts after being swallowed. For example, iL3s of the ruminant parasite Haemonchus contortus inhabit the soil and infect after being swallowed by grazing animals (O'Connor et al., 2006). After entering a host, the nematodes exsheath in the rumen and travel to the abomasum, where they develop into parasitic adults (Laing et al., 2013). Similarly, the murine gastrointestinal parasite Heligmosomoides polygyrus has an iL3 stage that can infect mice either from feces during coprophagy or from the fur during grooming (Hernandez and Sukhdeo, 1995). Despite their passive route of infection, both Haemonchus contortus and Heligmosomoides polygyrus actively migrate towards host-associated sensory cues. This suggests that these species use host-associated cues to position themselves in the vicinity of potential hosts, where they are more likely to be ingested (Hernandez and Sukhdeo, 1995; Castelletto et al., 2014; Ruiz et al., 2017; Bryant et al., 2018).

Examination of the $\mathrm{CO}_{2}$-evoked behaviours of Haemonchus contortus and Heligmosomoides polygyrus revealed that both species show experience-dependent responses to $\mathrm{CO}_{2}$ (Fig. 1C) (Castelletto et al., 2014; Ruiz et al., 2017). In the case of Heligmosomoides polygyrus, iL3s extracted directly from feces are repelled by $\mathrm{CO}_{2}$, while iL3s that have been removed from feces for multiple days - a condition designed to mimic the soil environment of iL3s - are attracted to $\mathrm{CO}_{2}$ (Ruiz et al., 2017). This shift in $\mathrm{CO}_{2}$ preference appears to occur as a result of the drop in ambient $\mathrm{CO}_{2}$ levels experienced by the iL3s after they migrate off feces, since cultivating iL3s off feces under high $\mathrm{CO}_{2}$ conditions $\left(2.5 \% \mathrm{CO}_{2}\right)$ prevents the behavioural switch. The initial repulsion from $\mathrm{CO}_{2}$ experienced by Heligmosomoides polygyrus iL3s on feces may enable them to disperse off of feces and into the environment to host seek. Following a prolonged period without feces, $\mathrm{CO}_{2}$ attraction may drive them towards new hosts or fresh host feces to increase their chances of host entry through ingestion (Ruiz et al., 2017).

In the case of Haemonchus contortus, iL3s directly removed from feces are neutral to $\mathrm{CO}_{2}$, whereas iL3s that have been 
A Chemotaxis assay

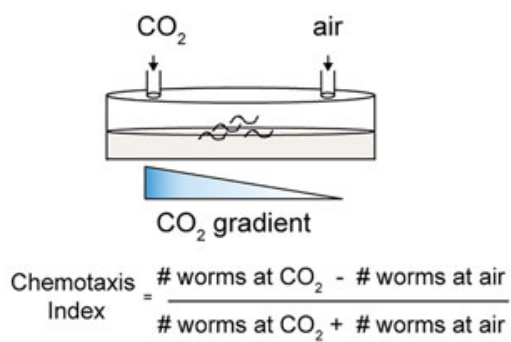

B Responses of skin-penetrating nematodes to $\mathrm{CO}_{2}$

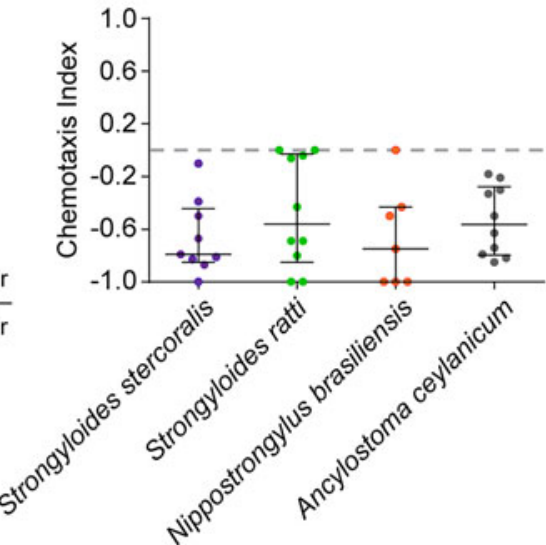

C Experience-dependent $\mathrm{CO}_{2}$ responses of passively ingested nematodes

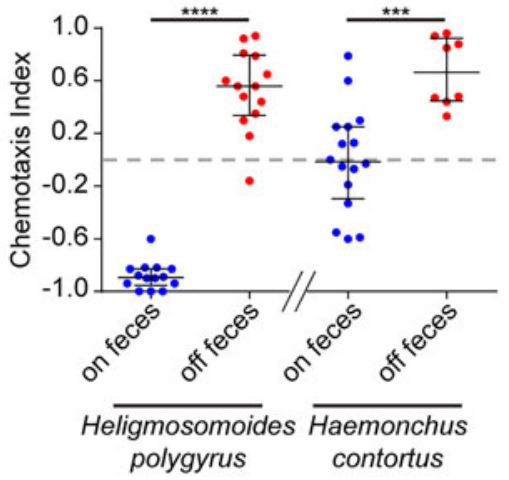

Fig. 1. Behavioural responses of mammalian-parasitic nematodes to $\mathrm{CO}_{2}$. (A) $\mathrm{ACO}_{2}$-chemotaxis assay. $\mathrm{CO}_{2}$ and air are pumped into opposite sides of a $10 \mathrm{~cm}$ plate. Infective larvae (iL3s) are placed at the centre and allowed to migrate for $1 \mathrm{~h}$. A chemotaxis index is then calculated according to the formula indicated; a positive index indicates attraction and a negative index indicates repulsion. (B) Behavioural responses of skin-penetrating iL3s to $10 \% \mathrm{CO}_{2}$. All species tested are repelled by $\mathrm{CO}_{2}$. Data are from Castelletto et al. (2014) and Ruiz et al. (2017). (C) Experience-dependent changes in $\mathrm{CO}_{2}$ responsiveness in the passively ingested nematodes Heligmosomoides polygyrus and Haemonchus contortus. $\mathrm{CO}_{2}$ responses switch from repulsion (in Heligmosomoides polygyrus) or neutral (in Haemonchus contortus)

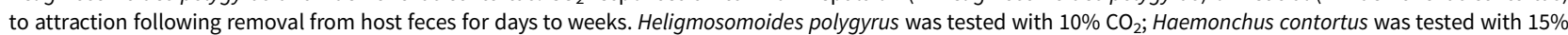
$\mathrm{CO}_{2}$. Figure adapted from Ruiz et al. (2017). Graphs show medians and interquartile ranges. ${ }^{\star \star \star \star} P<0.0001$, ${ }^{\star \star \star} P<0.001$, Mann-Whitney test for each species.

removed from feces for a week or more are attracted to $\mathrm{CO}_{2}$ (Castelletto et al., 2014; Ruiz et al., 2017). This experiencedependent shift in $\mathrm{CO}_{2}$-evoked behaviour may enable the iL3s to migrate towards the mouths of grazing ruminants, whose breath emits high concentrations of $\mathrm{CO}_{2}$ (Ruiz et al., 2017). In contrast to Heligmosomoides polygyrus and Haemonchus contortus, the skin-penetrating nematodes Ancylostoma ceylanicum, Strongyloides stercoralis and Strongyloides ratti do not display this flexibility in their behavioural responses to $\mathrm{CO}_{2}$. Thus, experience-dependent plasticity towards $\mathrm{CO}_{2}$ may be unique to passively ingested nematodes (Ruiz et al., 2017). However, skinpenetrating nematodes do show other forms of sensory plasticity, including experience-dependent thermal plasticity and temperature-dependent olfactory plasticity (Lee et al., 2016; Bryant et al., 2018). This suggests that experience-dependent responses to $\mathrm{CO}_{2}$ may not be beneficial for skin-penetrating nematodes, likely because the skin surface of mammals emits only very low levels of $\mathrm{CO}_{2}$ (Alkalay et al., 1971).

\section{The role of $\mathrm{CO}_{2}$ in mammalian-parasitic nematode development and physiology}

In addition to being a robust behavioural cue for parasitic nematodes, $\mathrm{CO}_{2}$ is also an important regulator of their development and physiology. For example, $\mathrm{CO}_{2}$ stimulates exsheathment and activation (exit from the developmentally arrested iL3 stage) in passively ingested ruminant parasites such as Haemonchus contortus (Rogers and Sommerville, 1960; Taylor and Whitlock, 1960; Sommerville, 1964; Bekelaar et al., 2018, 2019). However, the requirement for $\mathrm{CO}_{2}$ during exsheathment varies across species. $\mathrm{CO}_{2}$ is an absolute requirement for the exsheathment of Haemonchus contortus iL3s, whereas $\mathrm{CO}_{2}$ enhances but is not required for exsheathment in other passively ingested abomasal nematodes (Bekelaar et al., 2018). In the dog hookworm Ancylostoma caninum, $\mathrm{CO}_{2}$ is not required for activation but results in a slight increase in the rate of activation (Hawdon and Schad, 1990).

The role of $\mathrm{CO}_{2}$ is not limited to exsheathment and activation. $\mathrm{CO}_{2}$, in combination with $\mathrm{O}_{2}$, also regulates the development of Strongyloides ratti into either free-living adults or iL3s (Taylor and Weinstein, 1990). In addition, $\mathrm{CO}_{2}$ stimulates egg hatching in the giant roundworm Ascaris lumbricoides, a human-parasitic species that infects when eggs containing developmentally arrested infective larvae are swallowed by hosts as a result of fecal-oral contamination (Fairbairn, 1961; Dold and Holland, 2011). Finally, $\mathrm{CO}_{2}$ is required for the in vitro development of parasitic larvae in the pig roundworm Ascaris suum (Douvres and Urban, 1983). Thus, $\mathrm{CO}_{2}$ influences both behaviour and development in many if not all mammalian-parasitic nematode species.

\section{Responses of entomopathogenic nematodes to $\mathrm{CO}_{2}$}

\section{Introduction to entomopathogenic nematodes}

Entomopathogenic nematodes (EPNs) are parasites that infect and kill insects (Dillman and Sternberg, 2012). They are considered beneficial for humans due to their role as biological agents for pest control, and are likely also important for maintaining balanced ecosystems in nature. EPNs of the genera Heterorhabditis and Steinernema have been successfully employed commercially against insect agricultural pests (Liu et al., 2000; Grewal et al., 2005; Dillman and Sternberg, 2012; Labaude and Griffin, 2018). The geographical distribution of EPNs spans all continents except Antarctica (Hominick, 2002). Some EPNs, such as Steinernema carpocapsae and Heterorhabditis bacteriophora, are generalists that can infect many different insects; in contrast, other EPNs have very narrow host ranges (Peters, 1996). For example, the specialist Steinernema scapterisci specifically infects mole crickets, and the specialist Steinernema diaprepesi specifically infects the larval stages of the citrus pest Diaprepes abbreviatus (Nguyen and Smart, 1991; Nguyen and Hunt, 2007; Ali et al., 2010). EPNs infect only as third-stage larvae called infective juveniles (IJs); the IJ stage of EPNs is equivalent to the iL3 stage of mammalian-parasitic nematodes (Dillman et al., 2012a). IJs enter their insect hosts through a body orifice such as the mouth, spiracles or anus; IJs of some species can also penetrate directly through the cuticle (Bedding and Molyneux, 1982; Kaya and Gaugler, 1993). The IJs then enter the insect haemocoel and release a bacterial symbiont from their intestine (Bedding and 
Molyneux, 1982; Kaya and Gaugler, 1993). Toxins secreted by the nematode and the bacteria kill the insect, typically within $48 \mathrm{~h}$ (Kaya and Gaugler, 1993; Lu et al., 2017; Chang et al., 2019). The nematodes then feed on the insect cadaver and complete their parasitic life cycle. The nematodes can cycle through multiple generations in the host cadaver until resources are depleted, at which point new IJs form and disperse into the environment to seek out new hosts (Kaya and Gaugler, 1993).

\section{The role of $\mathrm{CO}_{2}$ in the host-seeking behaviours of EPNs}

The host-seeking strategies of EPNs vary across species. Some species are considered 'cruisers' that actively migrate towards stationary hosts, other species are considered 'ambushers' that remain relatively stationary and nictate to facilitate attachment to mobile hosts, and still other species use an intermediate strategy (Campbell and Gauger, 1993; Lewis, 2002; Lewis et al., 2006). However, both ambushers and cruisers are capable of migrating towards host-emitted chemosensory cues, suggesting that all EPNs engage in chemosensory-driven navigation towards hosts (Schmidt and All, 1979; Pye and Burman, 1981; O'Halloran and Burnell, 2003; Hallem et al., 2011a; Dillman et al., 2012b; Castelletto et al., 2014; Lee et al., 2016). Some EPNs in the genus Steinernema also engage in a unique jumping behaviour where the IJ stands on its tail and then propels itself into the air, presumably to facilitate host attachment as well as transport to new niches (Campbell and Kaya, 1999). Jumping can be stimulated by exposure to host-emitted chemosensory cues (Campbell and Kaya, 1999, 2000; Hallem et al., 2011a; Dillman et al., 2012b).

Many EPNs, including Heterorhabitis bacteriophora, Steinernema carpocapsae, Steinernema riobrave, Steinernema scapterisci and Steinernema glaseri, are attracted to $\mathrm{CO}_{2}$ (Fig. 2A) (Gaugler et al., 1980, 1991; Lewis et al., 1993; Robinson, 1995; Hallem et al., 2011a; Dillman et al., 2012b; Lee et al., 2016). This group includes both specialists and generalists, and both ambushers and cruisers. In addition, $\mathrm{CO}_{2}$ stimulates jumping in Steinernema carpocapsae, Steinernema riobrave and Steinernema scapterisci IJs at concentrations as low as $0.08 \%$ (approximately two times higher than atmospheric levels), suggesting that jumping is highly sensitive to environmental $\mathrm{CO}_{2}$ (Hallem et al., 2011a; Dillman et al., 2012b). Both the attractive responses of EPNs towards the odour of live insect hosts and jumping responses to host odour are decreased when $\mathrm{CO}_{2}$ is chemically removed using a soda lime filter, illustrating the importance of $\mathrm{CO}_{2}$ for host seeking (Gaugler et al., 1991; Dillman et al., 2012b). However, the extent to which host attraction is reduced in the absence of $\mathrm{CO}_{2}$ varies across different EPNhost combinations (Dillman et al., 2012b). Thus, $\mathrm{EPNs}$ use $\mathrm{CO}_{2}$ in combination with host-specific olfactory cues to migrate towards insects. $\mathrm{CO}_{2}$ also acts synergistically with plant root volatiles to attract some EPNs to plants infested with insects (Turlings et al., 2012).

Like some mammalian-parasitic nematodes, some EPNs exhibit plasticity in their olfactory responses to $\mathrm{CO}_{2}$. For example, the IJs of Steinernema scapterisci are repelled by $\mathrm{CO}_{2}$ immediately after emergence from the insect host, but their response shifts to robust attraction over the course of weeks (Fig. 2B) (Lee et al., 2016). In addition, the rate at which this shift occurs varies depending on the cultivation temperature of the IJs, with the shift occurring more rapidly in IJs cultured at $15^{\circ} \mathrm{C}$ relative to IJs cultured at $25^{\circ} \mathrm{C}$ (Lee et al., 2016). The change in $\mathrm{CO}_{2}$ preference correlates with a corresponding change in responses to host odours, including the odour of its natural host, the mole cricket (Lee et al., 2016). The strong repulsion of newly emerged Steinernema scapterisci IJs to $\mathrm{CO}_{2}$ and host odours may serve as a dispersal mechanism to drive them towards new niches. The mechanisms that drive the change in $\mathrm{CO}_{2}$ preference following host emergence in Steinernema scapterisci have not yet been elucidated. An intriguing possibility is that the $\mathrm{CO}_{2}$ repulsion exhibited by IJs immediately following host emergence could result from the elevated levels of $\mathrm{CO}_{2}$ experienced inside the decaying insect cadaver, similar to the way in which $\mathrm{CO}_{2}$ repulsion in Heligmosomoides polygyrus iL3s results from the elevated levels of $\mathrm{CO}_{2}$ experienced on mammalian feces (Ruiz et al., 2017). However, additional experiments will be necessary to determine whether the change in $\mathrm{CO}_{2}$ preference over time (or age) in Steinernema scapterisci is in fact regulated by ambient $\mathrm{CO}_{2}$ levels.

\section{Responses of plant-parasitic nematodes to $\mathrm{CO}_{2}$}

\section{Introduction to plant-parasitic nematodes}

Plant-parasitic nematodes (PPNs) are a major cause of agricultural crop damage throughout the world. It has been estimated that PPNs are responsible for approximately 100 billion dollars of crop loss per year worldwide (Jasmer et al., 2003; Wrather et al., 2003). Of over 4100 species of PPNs that have been identified (Decraemer and Hunt, 2006), the ones that cause the most severe economic loss are the nematodes that infect the roots of major agricultural crops (Bernard et al., 2017). These PPNs prevent water and nutrient uptake by plant roots, which results in greatly reduced crop quality and yield (Bernard et al., 2017).

\section{Responses of PPNs to $\mathrm{CO}_{2}$}

$\mathrm{CO}_{2}$ is ubiquitously produced by the roots of plants. Several studies have demonstrated an important role for $\mathrm{CO}_{2}$ in mediating attraction of PPNs to their host plants. For example, the stem nematode Ditylenchus dipsaci, which infects onion and garlic, migrates towards $\mathrm{CO}_{2}$ (Klingler, 1972; Viglierchio, 1990). Many other PPNs, including species from the genera Ditylenchus, Meloidogyne, Heterodera and Pratylenchus, are also attracted to $\mathrm{CO}_{2}$ (Johnson and Viglierchio, 1961; Prot, 1980; McCallum and Dusenbery, 1992; Robinson, 1995). In the case of Meloidogyne incognita, attraction to tomato root volatiles appears to be due to the presence of $\mathrm{O}_{2}$ and $\mathrm{CO}_{2}$ in the volatile mix (McCallum and Dusenbery, 1992). However, a more recent study found that for Meloidogyne hapla, the attractant is not $\mathrm{CO}_{2}$ itself but rather the low $\mathrm{pH}$ environment created by dissolved $\mathrm{CO}_{2}$ (Wang et al., 2009). In the case of the pine wilt nematode Bursaphelenchus xylophilus, the fourth-stage juveniles $\left(\mathrm{J}_{\mathrm{IV}} \mathrm{s}\right)$ are repelled by $\mathrm{CO}_{2}$. $\mathrm{CO}_{2}$ repulsion by $\mathrm{J}_{\mathrm{IV}}$ s plays an important role in dispersal from its insect vector, the pine sawyer beetle, into the pine tree (Wu et al., 2019). Bursaphelenchus xylophilus $\mathrm{J}_{\mathrm{IV}} \mathrm{s}$ enter the beetle tracheal system, where they are transported by the beetle to new pine trees. As the beetle matures and feeds on the pine tree, $\mathrm{CO}_{2}$ levels in the beetle tracheal system increase. Once $\mathrm{CO}_{2}$ levels reach a certain concentration, $\mathrm{CO}_{2}$ repulsion drives the $\mathrm{J}_{\mathrm{IV}} \mathrm{s}$ out of the beetle spiracles and into the pine tree (Wu et al., 2019). Thus, the responses of $\mathrm{PPNs}$ to $\mathrm{CO}_{2}$ vary greatly across species. A better understanding of how other PPNs respond to $\mathrm{CO}_{2}$ may enable the development of new biocontrol strategies.

\section{Responses of free-living nematodes to $\mathrm{CO}_{2}$}

\section{Introduction to free-living nematodes}

Free-living nematodes are found in a wide range of ecological habitats. These include various types of soil, sediment and organic matter, as well as marine and freshwater environments. Free-living nematodes use a wide variety of sensory cues to navigate their environment in search of food and mates, and to escape 
Responses of entomopathogenic nematodes to $\mathrm{CO}_{2}$

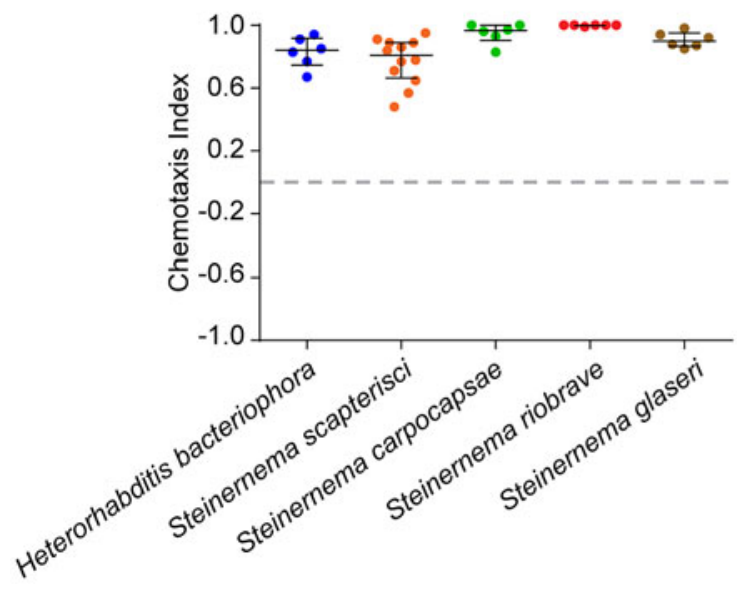

B Responses of Steinernema scapterisci to $\mathrm{CO}_{2}$

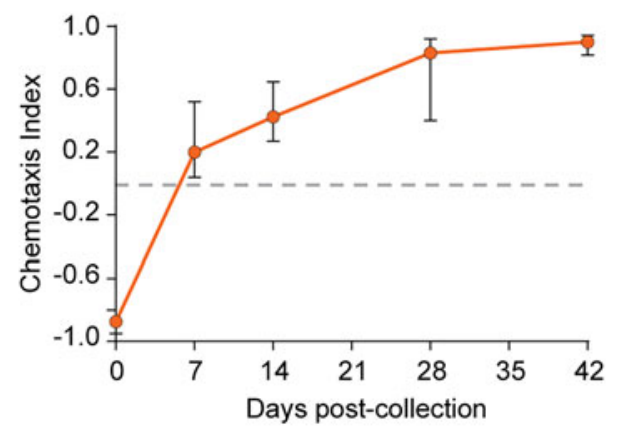

Fig. 2. Behavioural responses of entomopathogenic nematodes (EPNs) to $\mathrm{CO}_{2}$. (A) Behavioural responses of the infective juveniles (IJs) of various EPN species to $\mathrm{CO}_{2}$ in a chemotaxis assay (Fig. 1A). All EPNs tested showed attraction to $2.5 \% \mathrm{CO}_{2}$. Data are from Dillman et al. (2012b) and Hallem et al. (2011a). (B) Age-dependent changes in the $\mathrm{CO}_{2}$ preferences of Steinernema scapterisci IJs. IJs were grown at room temperature (approximately $22{ }^{\circ} \mathrm{C}$ ) and then incubated at $15{ }^{\circ} \mathrm{C}$ until the indicated time points (days post-collection). $\mathrm{CO}_{2}$ responsiveness changes from repulsion to attraction with age. IJs were tested with $1 \% \mathrm{CO}_{2}$. Data are from Lee et al. (2016). The graph shows medians and interquartile ranges.

from predators and pathogens. $\mathrm{CO}_{2}$ is universally present in terrestrial and aquatic habitats, and may serve as an important cue for survival and propagation of these nematodes. The most wellstudied free-living nematode is the model worm Caenorhabditis elegans. C. elegans is commonly found in microbe-rich environments such as those of fallen rotting fruits (Felix and Duveau, 2012), where $\mathrm{CO}_{2}$ is produced as one of many microbial byproducts. Consequently, C. elegans displays several behavioural and physiological responses to $\mathrm{CO}_{2}$.

\section{Behavioural responses of $\mathrm{C}$. elegans to carbon dioxide}

The first studies of $\mathrm{CO}_{2}$ responsiveness in C. elegans demonstrated that these worms undergo rapid changes in locomotion in response to changes in $\mathrm{CO}_{2}$ concentrations (Dusenbery, 1985). These responses are characterized by an overall decrease in movement and an increase in turning frequency (Dusenbery, 1985). A more recent study examining the effects of acute $\mathrm{CO}_{2}$ exposure found that freely moving well-fed adults reverse rapidly when their head is exposed to high levels of $\mathrm{CO}_{2}$, indicating that $\mathrm{CO}_{2}$ is an aversive cue for well-fed C. elegans adults (Hallem and Sternberg, 2008). In addition, well-fed C. elegans adults avoid high $\mathrm{CO}_{2}$ areas when allowed to migrate along a $\mathrm{CO}_{2}$ gradient in a $\mathrm{CO}_{2}$-chemotaxis assay (Fig. 3A) (Bretscher et al., 2008). For well-fed adults, $\mathrm{CO}_{2}$ may indicate the presence of potential predators or pathogens, and repulsion from $\mathrm{CO}_{2}$ may function as an escape mechanism.

As is the case for some parasitic nematodes, $\mathrm{CO}_{2}$ responsiveness in C. elegans is subject to experience-dependent plasticity. In the case of $C$. elegans, one of the factors that influences $\mathrm{CO}_{2}$ responsiveness is the worm's nutritional status. Depriving adults of food suppresses $\mathrm{CO}_{2}$ avoidance behaviour (Bretscher et al., 2008; Hallem and Sternberg, 2008). Moreover, as C. elegans adults are starved, $\mathrm{CO}_{2}$ response shifts from repulsion to attraction (Fig. 3A) (Rengarajan et al., 2019). The effects of starvation can be reversed when the animals are re-exposed to food (Rengarajan et al., 2019). The shift from $\mathrm{CO}_{2}$ repulsion to $\mathrm{CO}_{2}$ attraction in starved worms may be beneficial for survival, since starved animals must find food in order to survive and bacterial food emits $\mathrm{CO}_{2} \cdot \mathrm{CO}_{2}$ attraction by starved animals may also reflect an increased tolerance for risk taking; $\mathrm{CO}_{2}$ attraction is an inherently risky behaviour, since both predators and pathogens of C. elegans emit $\mathrm{CO}_{2}$ (Felix and Duveau, 2012; Brandt and Ringstad, 2015; Schulenburg and Felix, 2017).

$\mathrm{CO}_{2}$ responsiveness in $\mathrm{C}$. elegans adults is also modulated by recently experienced environmental $\mathrm{CO}_{2}$ and oxygen $\left(\mathrm{O}_{2}\right)$ levels, as well as immediate $\mathrm{O}_{2}$ context. For example, animals exposed to elevated $\mathrm{CO}_{2}$ levels $\left(2.5 \% \mathrm{CO}_{2}\right)$ become robustly attracted to $\mathrm{CO}_{2}$ over the course of hours in a reversible manner (Fig. 3A) (Guillermin et al., 2017). Prior exposure to low $\mathrm{O}_{2}$ levels also suppresses $\mathrm{CO}_{2}$ avoidance in adults, an effect that depends on the hypoxia inducible factor gene hif-1 (Fig. 3B) (Bretscher et al., 2008). In addition, whether animals have been pre-exposed to low $\mathrm{O}_{2}$ affects their responsiveness to $\mathrm{CO}_{2}$ stimuli under some conditions (Fenk and de Bono, 2017). $\mathrm{CO}_{2}$ responsiveness is also modulated by ambient $\mathrm{O}_{2}$ levels such that animals assayed under low $\mathrm{O}_{2}$ conditions are more strongly repelled by $\mathrm{CO}_{2}$ than animals assayed under high $\mathrm{O}_{2}$ conditions (Carrillo et al., 2013; Kodama-Namba et al., 2013). C. elegans prefers $\mathrm{O}_{2}$ concentrations below atmospheric (Gray et al., 2004); however, when exposed to opposing gradients of $\mathrm{O}_{2}$ and $\mathrm{CO}_{2}$, the avoidance response to high $\mathrm{CO}_{2}$ dominates over the avoidance response to high $\mathrm{O}_{2}$ (Bretscher et al., 2008). In nature, C. elegans is found in rotting vegetation (Felix and Braendle, 2010; Schulenburg and Felix, 2017), where both $\mathrm{O}_{2}$ and $\mathrm{CO}_{2}$ concentrations fluctuate. Moreover, both $\mathrm{O}_{2^{-}}$and $\mathrm{CO}_{2}$-sensing pathways control foraging behaviour (Bendesky et al., 2011; Milward et al., 2011; Juozaityte et al., 2017). Thus, the interplay between $\mathrm{O}_{2}$ - and $\mathrm{CO}_{2}$-evoked behaviours likely contributes to the ability of $C$. elegans to navigate the complex organic environments it inhabits.

$\mathrm{CO}_{2}$ responsiveness is also modulated by the presence or absence of food, and prior temperature experience (Bretscher et al., 2008, 2011; Kodama-Namba et al., 2013). In the case of temperature-dependent modulation of $\mathrm{CO}_{2}$ responsiveness, animals cultivated at $22^{\circ} \mathrm{C}$ show enhanced repulsion to $1 \% \mathrm{CO}_{2}$ when assayed at $15^{\circ} \mathrm{C}$ compared with $22{ }^{\circ} \mathrm{C}$ (Kodama-Namba et al., 2013), suggesting an interaction between recent temperature experience and $\mathrm{CO}_{2}$ sensing. The ecological significance of this interaction is not yet clear, but it suggests that $\mathrm{CO}_{2}$ preferences may vary on a diurnal cycle as the ambient temperature fluctuates. Thus, $\mathrm{CO}_{2}$-evoked behaviours are regulated by multiple sensory 
A Changes in behavioral responses to $\mathrm{CO}_{2}$

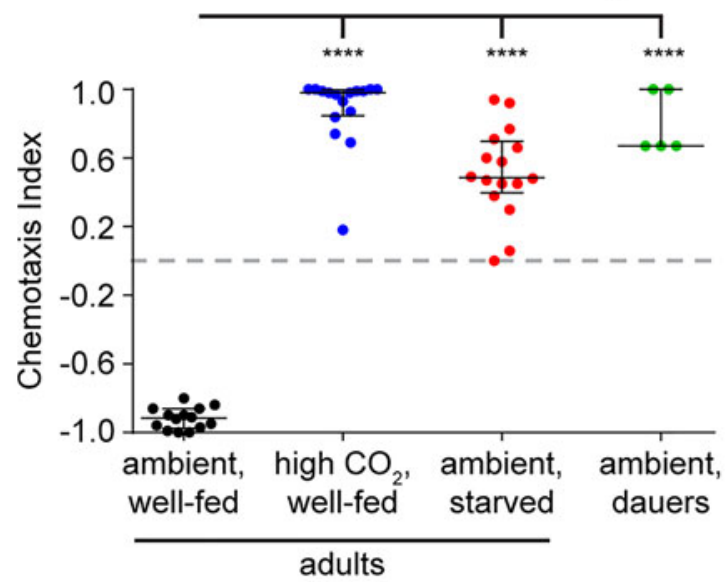

C Mechanisms underlying $\mathrm{CO}_{2}$ responsiveness

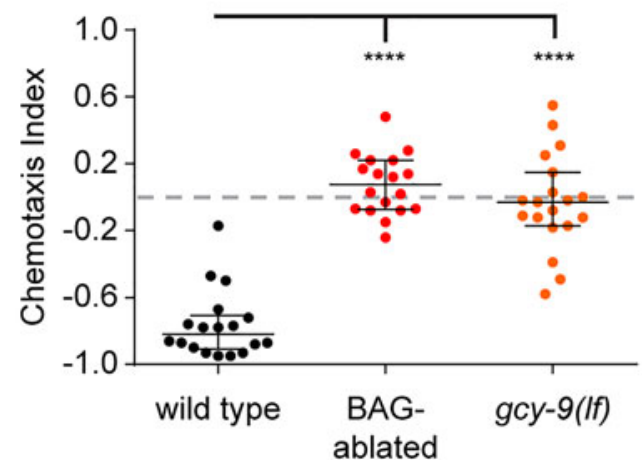

B Modulation of $\mathrm{CO}_{2}$ responsiveness by $\mathrm{O}_{2}$

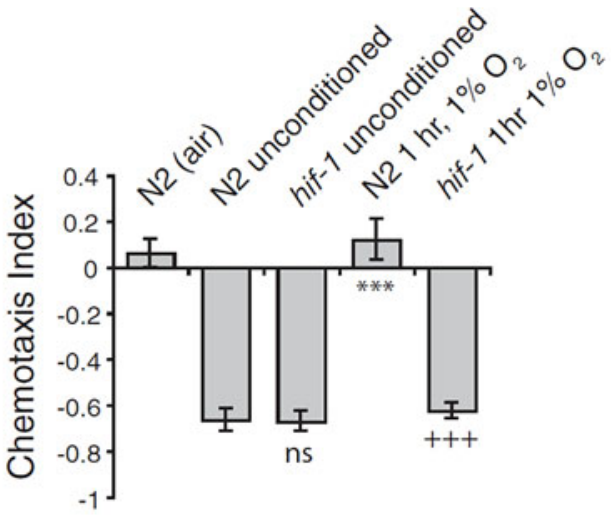

D

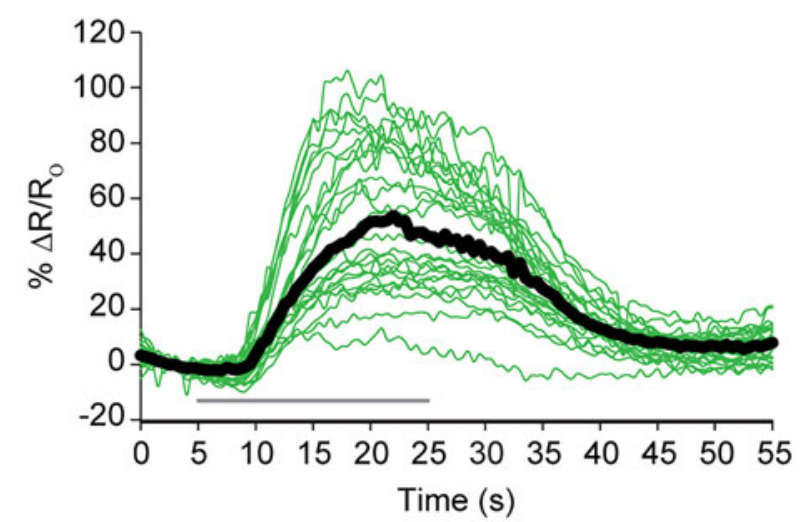

E Mechanisms underlying modulation of $\mathrm{CO}_{2}$ responsiveness in adults

\begin{tabular}{|c|c|c|c|c|}
\hline $\begin{array}{l}\text { Cultivation } \\
\text { conditions }\end{array}$ & $\begin{array}{r}\text { Sensory } \\
\text { neuron }\end{array}$ & Interneurons & Molecular signals & Behavior \\
\hline Ambient & & & $\begin{array}{c}\text { Dopamine } \\
\text { Neuropeptides }(n / p-1)\end{array}$ & $\mathrm{CO}_{2}$ repulsion \\
\hline High $\mathrm{CO}_{2}$ & & & Neuropeptides (flp-16) & $\mathrm{CO}_{2}$ attraction \\
\hline Starvation & & & $\begin{array}{l}\text { Octopamine } \\
\text { Neuropeptides }(n / p-1, \text { flp-16) }\end{array}$ & $\mathrm{CO}_{2}$ attraction \\
\hline
\end{tabular}

Fig. 3. Behavioural responses of $C$. elegans to $\mathrm{CO}_{2}$. (A) Responses of wild-type $C$. elegans adults and dauers to $\mathrm{CO}_{2}$ in a chemotaxis assay (Fig. $1 \mathrm{~A}$ ). Dauers are developmentally arrested third-stage larvae that are similar to parasitic iL3s and IJs (Hotez et al., 1993; Viney et al., 2005; Crook, 2014). Animals were either well-fed adults cultivated at ambient $\mathrm{CO}_{2}$, well-fed adults cultivated at high $\mathrm{CO}_{2}$, starved adults cultivated at ambient $\mathrm{CO}_{2}$ or dauer larvae cultivated at ambient $\mathrm{CO}_{2}$. Adults were tested in a $20 \mathrm{~min}$ assay; dauer larvae were tested in a $1 \mathrm{~h}$ assay. Responses shown are to $2.5 \% \mathrm{CO}_{2}$ (for adults cultivated at high $\mathrm{CO}_{2}$ ) or $10 \% \mathrm{CO}_{2}$ (for all other conditions). For the high $\mathrm{CO}_{2}$ condition, adults were cultivated at $2.5 \% \mathrm{CO}_{2}$ for one generation prior to the assay. For the starvation condition, adults were starved for $3 \mathrm{~h}$ prior to the assay. Data are from Guillermin et al. (2017), Rengarajan et al. (2019) and Hallem et al. (2011a). ${ }^{\star \star \star \star} P<0.0001$, one-way ANOVA with Dunnett's post-test. The graph shows medians and interquartile ranges. (B) Previously experienced hypoxic conditions modulate $\mathrm{CO}_{2}$ responsiveness in $\mathrm{C}$. elegans adults. Animals cultivated at low (1\%) oxygen for $1 \mathrm{~h}$ prior to assays showed decreased $\mathrm{CO}_{2}$ avoidance. This change is mediated by hypoxia inducible factor-1 (HIF-1), since hif-1 mutants are not affected by prior $\mathrm{O}_{2}$ exposure. ns, not significant relative to N2 (wild-type); ${ }^{\star \star \star} P<0.001$ relative to $\mathrm{N} 2 ;+++P<0.001$ relative to $\mathrm{N} 2$ exposed to $1 \% \mathrm{O}_{2}$ for $1 \mathrm{~h}$. The $\mathrm{N} 2$ (air) condition represents a control condition in which animals were not exposed to a $\mathrm{CO}_{2}$ gradient. The graph shows means and SEMs. Figure is from Bretscher et al. (2008), copyright 2008 National Academy of Sciences. (C) The BAG sensory neurons and GCY-9 are required for $\mathrm{CO}_{2}$ repulsion in C. elegans. BAG-ablated animals and gcy-9 loss-of-function (If) mutants are neutral to $\mathrm{CO}_{2} .{ }^{\star \star \star \star} P<0.0001$, one-way ANOVA with Dunnett's post-test. The graph shows medians and interquartile ranges. Data are from Carrillo et al. (2013). (D) Calcium activity in BAG neurons in response to $10 \% \mathrm{CO}_{2}$, as measured using the ratiometric calcium indicator yellow cameleon 3.60 (YC3.60). Green traces show responses of individual neurons; black line shows median response. Data are from Rengarajan et al. (2019). (E) A model for experience-dependent modulation of $\mathrm{CO}_{2}$ responsiveness in $\mathrm{C}$. elegans adults. Under ambient conditions, $\mathrm{CO}_{2}$ repulsion is mediated by activation of the RIA and RIG interneurons and inhibition of the AIY interneurons, and by both dopamine and neuropeptide signalling involving the neuropeptide gene $n l p-1 . \mathrm{CO}_{2}$ attraction in animals cultivated at high $\mathrm{CO}_{2}$ is mediated by activation of AIY, inhibition of RIA and silencing of RIG, as well as neuropeptide signalling involving the neuropeptide gene flp-16. Finally, $\mathrm{CO}_{2}$ attraction in starved adults is mediated by silencing of RIG and by a change in AIY responses such that activation and inhibition are observed with approximately equal frequency. Octopamine signalling and neuropeptide signalling via the neuropeptide genes $n l p-1$ and $f l p-16$ also promote $\mathrm{CO}_{2}$ attraction during starvation. Blue = excitatory activity, orange = inhibitory activity, grey $=$ silencing of activity. Figure is adapted from Guillermin et al. (2017) and Rengarajan et al. (2019). 
modalities, resulting in both context-dependent and experiencedependent responses to $\mathrm{CO}_{2}$.

$\mathrm{CO}_{2}$ can also elicit behavioural changes in C. elegans that are independent of changes in locomotion. For example, exposing C. elegans to high $\mathrm{CO}_{2}$ levels $\left(5 \% \mathrm{CO}_{2}\right)$ inhibits egg-laying behaviour, at least transiently (Fenk and de Bono, 2015). Modulation of egg-laying behaviour by high $\mathrm{CO}_{2}$ levels may prevent animals from exposing their progeny to unfamiliar environmental conditions. Feeding behaviour is also altered by $\mathrm{CO}_{2}$ such that brief exposure to high $\mathrm{CO}_{2}$ levels causes an acute reduction in pharyngeal pumping (Sharabi et al., 2009). Well-fed animals stop pharyngeal pumping when exposed to a lower concentration of $\mathrm{CO}_{2}$ than starved animals, suggesting that this behavioural change is dependent on the nutritional state of the animal (Sharabi et al., 2009).

Finally, C. elegans exhibits life-stage-specific responses to $\mathrm{CO}_{2}$. C. elegans dauers, which are developmentally arrested third-stage larvae that are similar to the iL3 and IJ stages of parasitic nematodes (Hotez et al., 1993; Viney et al., 2005; Crook, 2014), are attracted to $\mathrm{CO}_{2}$ (Fig. 3A) (Hallem et al., 2011a). Dauer larvae form when food is limited or environmental conditions are otherwise unfavourable ( $\mathrm{Hu}, 2007)$, and $\mathrm{CO}_{2}$ attraction by dauers may enable them to locate bacterial food sources. In addition, dauers associate with invertebrates such as slugs, snails and isopods, which act as carriers that facilitate their dispersal to new niches (Baird, 1999; Caswell-Chen et al., 2005; Lee et al., 2012; Schulenburg and Felix, 2017). Thus, $\mathrm{CO}_{2}$ attraction may also enable dauers to locate and associate with invertebrate carriers.

\section{Effects of $\mathrm{CO}_{2}$ on $\mathrm{C}$. elegans development and physiology}

High levels of $\mathrm{CO}_{2}$ can also elicit physiological changes in C. elegans. Cultivating animals at $\mathrm{CO}_{2}$ levels above $9 \% \mathrm{CO}_{2}$ decreases brood size and significantly slows the rate of embryonic development (Sharabi et al., 2009). This developmental delay is not caused by any obvious reduction in the overall health of the embryos or the adults that develop from these embryos. In addition, chronic exposure ( $>4$ days) to $19 \% \mathrm{CO}_{2}$ causes defects in overall body muscle morphology, resulting in long-lasting movement defects (Sharabi et al., 2009). Nevertheless, cultivation at $19 \% \mathrm{CO}_{2}$ extends lifespan, an effect that appears to be independent of the inhibitory effect of $\mathrm{CO}_{2}$ on egg laying (Sharabi et al., 2009). The lifespan extension induced by exposure to high $\mathrm{CO}_{2}$ also may be independent of the dietary restriction pathway, since eat-2 mutants, which show reduced pharyngeal pumping, show increased lifespan at high $\mathrm{CO}_{2}$ (Sharabi et al., 2009). Thus, $\mathrm{CO}_{2}$ has diverse effects on $C$. elegans development, physiology and behaviour.

\section{Behavioural and physiological responses of other free-living nematodes to $\mathrm{CO}_{2}$}

Other free-living nematodes show diverse responses to $\mathrm{CO}_{2}$. For example, the free-living marine nematode Adoncholaimus thalassophygas is attracted to $\mathrm{CO}_{2}$ (Riemann and Schrage, 1988). This effect is not due to a general decrease in the $\mathrm{pH}$ of the medium, since the addition of hydrochloric acid did not elicit a similar attractive response (Riemann and Schrage, 1988). $\mathrm{CO}_{2}$ is emitted from bacteria present in decaying carcasses found in sediments and may act as a food signal for these nematodes. The necromenic nematode Pristionchus pacificus, which represents an evolutionary intermediate between free-living and parasitic nematodes, displays acute $\mathrm{CO}_{2}$ avoidance (Hallem and Sternberg, 2008). In contrast, the free-living nematodes Caenorhabditis briggsae, Caenorhabditis angaria and Panagrellus redivivus do not respond to $\mathrm{CO}_{2}$ in acute avoidance assays (Hallem and Sternberg, 2008). However, ambient $\mathrm{CO}_{2}$ concentrations play a prominent role in regulating reproduction in Panagrellus redivivus. Under low $\mathrm{O}_{2}$ conditions, the brood size of Panagrellus redivivus increases in response to an increase in $\mathrm{CO}_{2}$ concentration from 0 to $5 \%$ (Hansen and Buecher, 1970). The effects of $\mathrm{CO}_{2}$ on nematode physiology also vary greatly across species. At the extreme, nematodes have been isolated from volcanic gas vents, where $\mathrm{CO}_{2}$ levels can reach $100 \%$; these nematodes can survive under $100 \% \mathrm{CO}_{2}$ conditions for at least 5 days (Pilz and Hohberg, 2015). Thus, $\mathrm{CO}_{2}$ has species-specific effects on nematode behaviour and physiology.

Cellular and molecular mechanisms of $\mathrm{CO}_{2}$ responsiveness in nematodes

\section{Cellular mechanisms of $\mathrm{CO}_{2}$ responsiveness in $\mathrm{C}$. elegans}

The primary $\mathrm{CO}_{2}$-sensing neurons in C. elegans are the paired BAG neurons in the head. Ablation of the BAG neurons abolishes both $\mathrm{CO}_{2}$ avoidance in adults (Hallem and Sternberg, 2008) and $\mathrm{CO}_{2}$ attraction in dauers (Fig. 3C) (Hallem et al., 2011a). Exposing animals to varying concentrations of $\mathrm{CO}_{2}$ produces dose-dependent calcium activity in the BAG neurons in vivo (Fig. 3D) (Hallem et al., 2011b). In addition, isolated BAG neurons derived from $C$. elegans embryos respond to $\mathrm{CO}_{2}$ in vitro, suggesting that BAG neurons are intrinsically sensitive to $\mathrm{CO}_{2}$ (Smith et al., 2013). The calcium responses in isolated BAG neurons in culture are independent of carbonic anhydrase activity, indicating that these neurons can sense molecular $\mathrm{CO}_{2}$. Moreover, a majority of isolated BAG neurons do not respond to $\mathrm{pH}$, although responses to low $\mathrm{pH}$ are detectable in some isolated BAG neurons (Smith et al., 2013). However, the role of BAG neurons is not limited to promoting $\mathrm{CO}_{2}$ responses. The BAG neurons also sense $\mathrm{O}_{2}$ (Zimmer et al., 2009). Furthermore, they play a role in establishing food odour preferences and in foraging behaviour (Harris et al., 2014; Juozaityte et al., 2017). In addition to BAG neurons, other sensory neurons including ASE, AFD, AWC, ASJ, ASK, ASH and ADL also exhibit $\mathrm{CO}_{2}$-evoked calcium activity and contribute to $\mathrm{CO}_{2}$ responsiveness (Bretscher et al., 2011; Fenk and de Bono, 2015). The interneurons AIY, RIG, RIA and AIZ act downstream of BAG neurons to mediate $\mathrm{CO}_{2}$-evoked behaviour (Kodama-Namba et al., 2013; Guillermin et al., 2017). The AIA interneurons also show $\mathrm{CO}_{2}$-evoked activity and are involved in $\mathrm{CO}_{2}$ responsiveness (Fenk and de Bono, 2015). In well-fed adults, $\mathrm{CO}_{2}$ repulsion is correlated with activation of RIA, RIG and AIZ, and inhibition of AIY (Fig. 3E) (Guillermin et al., 2017).

\section{Molecular mechanisms of $\mathrm{CO}_{2}$ responsiveness in $\mathrm{C}$. elegans}

The detection of $\mathrm{CO}_{2}$ by the BAG neurons requires the receptortype guanylate cyclase GCY-9. Animals with loss-of-function mutations in $g c y-9$ are insensitive to $\mathrm{CO}_{2}$ in behavioural assays (Fig. 3C) (Hallem et al., 2011b). Moreover, $\mathrm{CO}_{2}$-evoked calcium transients in the BAG neurons require GCY-9, and ectopic expression of GCY-9 confers $\mathrm{CO}_{2}$ sensitivity to other sensory neurons (Hallem et al., 2011b; Brandt et al., 2012; Carrillo et al., 2013). The expression of GCY-9 in the BAG neurons requires the E26 transformation-specific (ETS)-domain transcription factor ETS-5, and ets-5 mutants fail to avoid $\mathrm{CO}_{2}$ (Guillermin et al., 2011; Brandt et al., 2012). Both ETS-5 and the SoxD transcription factor EGL-13 are also required more generally for normal differentiation of the BAG neurons (Guillermin et al., 2011; Brandt et al., 2012; Petersen et al., 2013). The Toll-like receptor TOL-1 is also required for normal BAG neuron differentiation, 
and tol-1 mutants are defective in pathogen avoidance behaviour as a result (Brandt and Ringstad, 2015).

In addition to GCY-9, the cGMP signalling pathway that mediates $\mathrm{CO}_{2}$ detection consists of the cGMP-gated cation channel TAX-2/TAX-4 (Bretscher et al., 2008; Hallem and Sternberg, 2008). Glutamate signalling and neuropeptide signalling are also required for BAG-mediated responses to $\mathrm{CO}_{2}$ (Guillermin et al., 2017). BAG neurons are glutamatergic (Serrano-Saiz et al., 2013), and well-fed adults lacking the vesicular glutamate transporter EAT-4 show neutral responses to $\mathrm{CO}_{2}$ (Guillermin et al., 2017). BAG neurons also release neuropeptides, and well-fed adults lacking the BAG-expressed FMRFamide-like neuropeptide FLP-17 do not respond to $\mathrm{CO}_{2}$ (Guillermin et al., 2017). In addition, several other signalling molecules, including the calcineurin subunits TAX-6 and CNB-1, the regulator of G-protein signalling RGS-3 and the nuclear hormone receptor NHR-49 are known to regulate $\mathrm{CO}_{2}$ response (Hallem and Sternberg, 2008). The microRNA mir-791 is also required for the normal $\mathrm{CO}_{2}$-evoked calcium activity of the BAG neurons (Drexel et al., 2016).

\section{Mechanisms underlying the context-dependent modulation of $\mathrm{CO}_{2}$ responsiveness by $\mathrm{O}_{2}$}

The extent to which $\mathrm{CO}_{2}$ responsiveness is regulated by ambient $\mathrm{O}_{2}$ levels depends on the neuropeptide $\mathrm{Y}$ receptor NPR-1 (McGrath et al., 2009; Carrillo et al., 2013; Kodama-Namba et al., 2013). The laboratory wild-type (N2) strain of C. elegans contains a gain-of-function mutation in the $n p r-1$ gene that confers $\mathrm{CO}_{2}$ avoidance on well-fed adults regardless of ambient $\mathrm{O}_{2}$ levels. However, animals containing loss-of-function ( $l f)$ mutations in $n p r-1$ and animals carrying the natural variant of $n p r-1$ avoid $\mathrm{CO}_{2}$ under low $\mathrm{O}_{2}$ conditions but do not respond to $\mathrm{CO}_{2}$ at normal atmospheric $\mathrm{O}_{2}$ levels $\left(21 \% \mathrm{O}_{2}\right)$ (Carrillo et al., 2013; Kodama-Namba et al., 2013). The gain-of-function NPR-1 variant in $\mathrm{N} 2$ animals suppresses the activity of the $\mathrm{O}_{2}$-sensing URX neurons to promote $\mathrm{CO}_{2}$ avoidance regardless of ambient $\mathrm{O}_{2}$ levels. In animals containing an $n p r-1$ (lf) mutation or a natural variant of $n p r-1$, the URX neurons are tonically active under high $\mathrm{O}_{2}$ conditions and inhibit $\mathrm{CO}_{2}$ avoidance at high $\mathrm{O}_{2}$. The RIA interneurons appear to act downstream of URX to partially mediate its effects on the $\mathrm{CO}_{2}$ circuit (Kodama-Namba et al., 2013). In addition, the neuroglobin gene $g l b-5$ also acts via the URX neurons to modulate $\mathrm{CO}_{2}$ responsiveness as a function of ambient $\mathrm{O}_{2}$ levels (McGrath et al., 2009; Kodama-Namba et al., 2013).

\section{Mechanisms underlying the experience-dependent modulation of $\mathrm{CO}_{2}$ responsiveness}

The mechanisms underlying experience-dependent modulation of $\mathrm{CO}_{2}$ responsiveness in $C$. elegans have been elucidated in some detail. The shift in $\mathrm{CO}_{2}$ response from repulsion to attraction when animals are moved from low $\mathrm{CO}_{2}$ to high $\mathrm{CO}_{2}$ cultivation conditions results from the differential activity of a single set of interneurons downstream of the BAG sensory neurons (Guillermin et al., 2017). In animals that were previously cultivated at low $\mathrm{CO}_{2}, \mathrm{CO}_{2}$ exposure inhibits the AIY interneurons and activates the RIA and RIG interneurons. In contrast, in animals that have been cultivated at high $\mathrm{CO}_{2}, \mathrm{CO}_{2}$ exposure activates AIY and inhibits RIA. Moreover, RIG is silenced such that it no longer responds to $\mathrm{CO}_{2}$ (Fig. 3E). Thus, $\mathrm{CO}_{2}$ response is not determined by whether an 'attractive' or 'repulsive' pathway is activated; rather, it is determined by experience-dependent modulation of interneuron activity in a single pathway (Guillermin et al., 2017). A number of neuropeptides also differentially modulate $\mathrm{CO}_{2}$ responsiveness in animals cultured under high vs low $\mathrm{CO}_{2}$ conditions (Fig. 3E) (Guillermin et al., 2017).
The shift from $\mathrm{CO}_{2}$ repulsion to $\mathrm{CO}_{2}$ attraction that occurs during starvation also arises due to the differential activities of the AIY and RIG interneurons (Rengarajan et al., 2019). In starved animals, RIG is silenced and AIY shows stochastic responses such that $\mathrm{CO}_{2}$ evokes activating and inhibiting responses with approximately equal frequency (Fig. 3E). At the molecular level, whether $\mathrm{CO}_{2}$ is attractive or repulsive is regulated by biogenic amine signalling. Dopamine promotes $\mathrm{CO}_{2}$ avoidance in well-fed animals by promoting activation of RIG and inhibition of AIY, while octopamine promotes $\mathrm{CO}_{2}$ attraction in starved animals by promoting activation of AIY (Fig. 3E) (Rengarajan et al., 2019). Thus, the $\mathrm{CO}_{2}$ circuit is modulated during starvation by opposing biogenic amine signals. Neuropeptide signalling also regulates $\mathrm{CO}_{2}$ responsiveness during starvation (Fig. 3E) (Rengarajan et al., 2019). Finally, $\mathrm{CO}_{2}$ attraction in dauer larvae is less well understood but is regulated at least in part by neuropeptide signalling (Lee et al., 2017).

\section{Molecular and cellular mechanisms underlying other $\mathrm{CO}_{2}$-evoked behaviours}

Some of the molecular and cellular mechanisms that mediate the effects of $\mathrm{CO}_{2}$ on other behaviours in C. elegans have also been elucidated. For instance, $\mathrm{CO}_{2}$-evoked activity in the AWC sensory neurons triggers a cGMP signalling pathway that ultimately inhibits the activity of the HSN neurons, resulting in the inhibition of egg-laying behaviour (Fenk and de Bono, 2015). Antagonistic effects of the BAG neurons and the URX neurons regulate lifespan in C. elegans, resulting in increased longevity in BAG-ablated animals (Liu and Cai, 2013). Mutations in the c-Jun N-terminal kinase (JNK) signalling pathway genes jnk-1 and $k g b$-2 suppress $\mathrm{CO}_{2}$-induced fertility defects, indicating that JNK signalling may be involved in regulating fertility in response to $\mathrm{CO}_{2}$ (Vadasz et al., 2012).

\section{Unanswered questions regarding $\mathrm{CO}_{2}$ responsiveness in C. elegans}

Although the mechanisms underlying $\mathrm{CO}_{2}$ responsiveness in C. elegans have been elucidated in appreciable detail, several questions remain unexplored. For example, more information is needed to fully understand how the differential flow of information from BAG neurons to downstream interneurons generates experience-dependent plasticity of $\mathrm{CO}_{2}$-evoked behaviour. One intriguing possibility is that the $\mathrm{BAG}$ neurons express or release different neurotransmitters or neuropeptides in response to $\mathrm{CO}_{2}$ under varying conditions. Consistent with this possibility, the BAG neurons modulate the expression of FLP-19 neuropeptides as a function of their $\mathrm{CO}_{2}$-evoked activity (Rojo Romanos et al., 2017). In addition, the interneurons that act downstream of other $\mathrm{CO}_{2}$-sensing neurons have not been identified. Finally, the $\mathrm{CO}_{2}$ microcircuit that drives $\mathrm{CO}_{2}$ attraction in dauers remains poorly understood, although it appears to involve dauer-specific, gap-junction-mediated signalling between the BAG neurons and the downstream AIB interneurons (Bhattacharya et al., 2019). In future studies, it will be interesting to determine whether the same set of neurons or a distinct set of neurons promotes $\mathrm{CO}_{2}$ attraction in dauers. A better understanding of the neural circuits and signalling pathways that regulate $\mathrm{CO}_{2}$ responsiveness as a function of experience, context and life stage will provide important insights into how a single sensory cue can give rise to diverse behavioural responses in an ethologically-appropriate manner. 


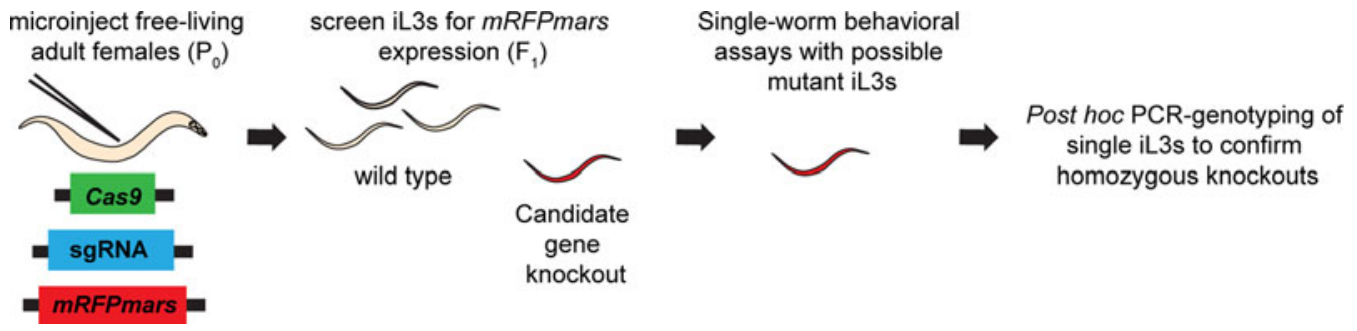

Fig. 4. Targeted mutagenesis in Strongyloides stercoralis. (A) Strategy for CRISPR/Cas9-mediated targeted mutagenesis in Strongyloides stercoralis. Plasmid vectors encoding Cas9, the single guide RNA (sgRNA) for the gene of interest and a repair template for homology-directed repair encoding an mRFPmars reporter are introduced into Strongyloides stercoralis free-living adult females $\left(P_{0}\right)$ by gonadal microinjection. The iL3 progeny $\left(F_{1}\right)$ from microinjected females are screened for mRFPmars expression, indicative of a possible disruption of the gene of interest. iL3s are then tested in single-worm chemotaxis assays and genotyped post hoc for homozygous disruption of the gene of interest. Figure is adapted from Gang et al. (2017).

\section{Mechanisms underlying $\mathrm{CO}_{2}$ responsiveness in other nematodes}

The anatomy and function of nematode sensory neurons are generally conserved across species (Ashton et al., 1995, 1999; Lopez et al., 2000; Li et al., 2000a, 2000b, 2001; Bhopale et al., 2001; Forbes et al., 2004; Ketschek et al., 2004; Ashton et al., 2007; Bumbarger et al., 2007; Srinivasan et al., 2008; Bumbarger et al., 2009; Zhu et al., 2011; Hallem et al., 2011a), making it possible to use knowledge of $\mathrm{CO}_{2}$ responsiveness in C. elegans as a starting point for launching investigations into the mechanisms of $\mathrm{CO}_{2}$ responsiveness in parasitic nematodes. In the case of both the necromenic nematode Pristionchus pacificus and the EPNs Heterorhabditis bacteriophora and Steinernema carpocapsae, BAG neurons were identified on the basis of conserved neuroanatomical position and shown to be required for behavioural responses to $\mathrm{CO}_{2}$ by laser ablation analyses (Hallem and Sternberg, 2008; Hallem et al., 2011a). BAG-ablated Pristionchus pacificus adults do not show acute $\mathrm{CO}_{2}$ avoidance, and BAG-ablated Heterorhabditis bacteriophora and Steinernema carpocapsae IJs do not show $\mathrm{CO}_{2}$ attraction (Hallem et al., 2011a). In addition, $\mathrm{CO}_{2}$-evoked jumping behaviour in Steinernema carpocapsae requires the BAG neurons (Hallem et al., 2011a). Thus, the neural circuits that mediate $\mathrm{CO}_{2}$ response are at least partly conserved across nematode species. However, the interneurons that operate downstream of BAG neurons to mediate $\mathrm{CO}_{2}$ responsiveness in other nematode species have not yet been identified. Moreover, nothing is currently known about the neural circuits and molecular signals that promote $\mathrm{CO}_{2}$ responsiveness in mammalian-parasitic nematodes. In future studies, it will also be interesting to determine whether similar or distinct mechanisms operate in C. elegans and parasitic nematodes to modulate $\mathrm{CO}_{2}$ responses depending on context, previous experience or life stage.

\section{Directions for future research}

A major focus going forward will be on elucidating the cellular and molecular mechanisms underlying $\mathrm{CO}_{2}$ responsiveness in mammalian-parasitic nematodes. The identification of the neural mechanisms that drive or regulate the $\mathrm{CO}_{2}$ responses of mammalian-parasitic nematodes both inside and outside the host could lead to the identification of new drug targets or new strategies for nematode control. Until recently, investigations into the mechanisms underlying sensory behaviours in parasitic nematodes were limited to laser ablation analysis due to the dearth of resources and tools required for the genetic manipulation of these parasites. Laser ablation analysis has been used to establish the function of a number of different sensory neurons in mammalian-parasitic nematodes, including Strongyloides stercoralis, hookworms and Haemonchus contortus (Ashton et al., 1998; Lopez et al., 2000; Li et al., 2000b; Bhopale et al., 2001; Forbes et al., 2004; Ketschek et al., 2004; Nolan et al., 2004; Ashton et al., 2007). However, several recent advances have facilitated the study of gene function and the genetic basis of sensory behaviours in these parasites. High-quality genome sequences of several nematode species have been identified and are readily accessible (Mitreva et al., 2007; Brindley et al., 2009; Hunt et al., 2016; Howe et al., 2017; International Helminth Genomes, 2019). Transcriptomic data are also now available for many parasitic nematode species (Jex et al., 2019), which may significantly advance the study of gene expression and the identification of novel signalling pathways that drive sensory behaviours.

The most genetically tractable parasitic nematodes are Strongyloides stercoralis and Strongyloides ratti. Strongyloides stercoralis and Strongyloides ratti are more readily amenable to genetic manipulation than other parasitic nematodes because they can undergo one free-living generation (Viney, 1999, 2006; Lok, 2007). Foreign DNA can be introduced by gonadal microinjection into free-living adults using techniques based on those originally developed for C. elegans (Evans, 2006). Most other mammalianparasitic nematodes lack a free-living generation, which makes it difficult to introduce foreign DNA into these worms. Strongyloides stercoralis is a human parasite that infects approximately 370 million people worldwide (Page et al., 2018) and is therefore of direct interest as a human pathogen; additionally, Strongyloides stercoralis is of interest as a model for other humanparasitic nematodes such as hookworms that cannot be genetically manipulated.

Transgenic nematodes can be generated by introducing plasmid DNA containing exogenous genes; these genes are then expressed as extrachromosomal arrays in the $\mathrm{F}_{1}$ progeny of the microinjected adults (Lok and Massey, 2002; Li et al., 2006, 2011; Junio et al., 2008; Lok and Artis, 2008; Lok, 2012; Shao et al., 2012; Lok et al., 2017; Shao et al., 2017). This technique can be potentially used to express any gene of choice, including those required for genetic ablation or silencing of neurons (Schiavo et al., 1992; Qi et al., 2012; Williams et al., 2013; Pokala et al., 2014) and those required for monitoring neuronal activity (Nagai et al., 2004; Chen et al., 2013; Dana et al., 2016). The targeted expression of exogenous genes in Strongyloides has been aided by the identification of several promoters that drive expression in single cells or subsets of cells (Junio et al., 2008; Stoltzfus et al., 2012; Bryant et al., 2018). However, whereas extrachromosomal arrays in C. elegans are stably expressed across generations, extrachromosomal arrays in Strongyloides are silenced after the $F_{1}$ generation by as-yet-unknown mechanisms (Junio et al., 2008; Li et al., 2011). Persistent expression across generations can be achieved in Strongyloides by methods that promote genomic integration of transgenes, such as transposon-mediated 
random integration (Shao et al., 2012; Lok, 2013) and CRISPR/ Cas9-mediated targeted integration (Gang et al., 2017).

Methods for disrupting gene function are also now available for Strongyloides stercoralis and Strongyloides ratti. The recent development of an approach for CRISPR/Cas9-mediated targeted gene disruption in these species provided the first insights into the genetic mechanisms that drive sensory behaviours (Fig. 4) (Gang et al., 2017; Lok et al., 2017; Bryant et al., 2018). For example, knockout of the gene encoding the cyclic-nucleotide-gated channel subunit TAX-4 severely disrupts the thermosensory behaviour of Strongyloides stercoralis infective larvae (Bryant et al., 2018). RNA interference (RNAi) has also now been successfully applied to Strongyloides ratti. RNAi approaches using both dsRNA and siRNA have been used to study the effects of transcriptional knockdown of genes in several parasitic nematode species, although with varying efficacy (Geldhof et al., 2006; Kotze and Bagnall, 2006; Visser et al., 2006; Kang and Hong, 2008; Lendner et al., 2008; Viney and Thompson, 2008; Samarasinghe et al., 2011; Britton et al., 2012; Zawadzki et al., 2012; Tzelos, 2014). In the case of Strongyloides ratti, a recent study demonstrated the first successful knockdown of multiple mRNAs using an siRNA approach (Dulovic and Streit, 2019). In addition, chemical mutagenesis has been used to perform unbiased forward genetic screens to generate dominant non-targeted mutations in Strongyloides ratti iL3s, although mapping the locations of these mutations has not been possible yet (Viney et al., 2002; Guo et al., 2015).

Using a combination of the above approaches, it should be possible to identify the neural mechanisms and molecular pathways that are involved in driving behavioural and physiological responses of Strongyloides stercoralis to $\mathrm{CO}_{2}$. For example, it will be interesting to determine whether the BAG neurons, which sense $\mathrm{CO}_{2}$ and promote behavioural responses to $\mathrm{CO}_{2}$ in C. elegans, play a similar role in Strongyloides stercoralis. It will also be important to elucidate the neural circuitry that operates downstream of the $\mathrm{CO}_{2}$-sensing neurons to mediate or modulate $\mathrm{CO}_{2}$-evoked behaviours in Strongyloides stercoralis. An intriguing possibility is that while sensory neuron function may be generally conserved across species, interneuron function may be less well conserved and may instead reflect species-specific behavioural and physiological responses to $\mathrm{CO}_{2}$. In addition, through the systematic screening of candidate genes known to be involved in $\mathrm{CO}_{2}$ responsiveness in C. elegans, it might be possible to uncover molecular signals that regulate parasite-host interactions or that are required for successful parasitism. In the long run, a better understanding of the molecular and cellular bases of $\mathrm{CO}_{2}$-evoked behaviours in parasitic nematodes may lead to new avenues for nematode control. It may also shed light on some of the unique sensory mechanisms that operate in parasitic nematodes to shape parasite-specific behavioural responses.

Acknowledgments. We thank Astra Bryant, Michelle Castelletto, Elisa Rojas-Palato, Felicitas Ruiz and Breanna Walsh for their insightful comments on the manuscript.

Financial support. This work was supported by the National Institutes of Health (1DP2DC014596 and 1R01DC017959 to E.A.H, and 1F32AI147617 to N.B.). E.A.H. is also supported by a Burroughs Wellcome Fund Investigators in the Pathogenesis of Disease Award and a Howard Hughes Medical Institute Faculty Scholar Award.

\section{References}

Ali JG, Alborn HT and Stelinski LL (2010) Subterranean herbivore-induced volatiles released by citrus roots upon feeding by Diaprepes abbreviatus recruit entomopathogenic nematodes. Journal of Chemical Ecology 36, 361-368.
Alkalay I, Suetsugu S, Constantine H and Stein M (1971) Carbon dioxide elimination across human skin. American Journal of Physiology 220, 1434-1436.

Ashton FT, Bhopale VM, Fine AE and Schad GA (1995) Sensory neuroanatomy of a skin-penetrating nematode parasite: Strongyloides stercoralis. I. Amphidial neurons. Journal of Comparative Neurology 357, 281-295.

Ashton FT, Bhopale VM, Holt D, Smith G and Schad GA (1998) Developmental switching in the parasitic nematode Strongyloides stercoralis is controlled by the ASF and ASI amphidial neurons. Journal of Parasitology 84, 691-695.

Ashton FT, Li J and Schad GA (1999) Chemo- and thermosensory neurons: structure and function in animal parasitic nematodes. Veterinary Parasitology 84, 297-316.

Ashton FT, Zhu X, Boston R, Lok JB and Schad GA (2007) Strongyloides stercoralis: amphidial neuron pair ASJ triggers significant resumption of development by infective larvae under host-mimicking in vitro conditions. Experimental Parasitology 115, 92-97.

Baird SE (1999) Natural and experimental associations of Caenorhabditis remanei with Trachelipus rathkii and other terrestrial isopods. Nematology 1, 471-475.

Bedding RA and Molyneux AS (1982) Penetration of insect cuticle by infective juveniles of Heterorhabditis spp. (Heterorhabditidae: Nematoda). Nematologica 28, 354-359.

Bekelaar K, Waghorn T, Tavendale M, McKenzie C and Leathwick D (2018) Carbon dioxide is an absolute requirement for exsheathment of some, but not all, abomasal nematode species. Parasitology Research 117, 3675-3678.

Bekelaar K, Waghorn T, Tavendale M, McKenzie C and Leathwick D (2019) Abomasal nematode species differ in their in vitro response to exsheathment triggers. Parasitology Research 118, 707-710.

Bendesky A, Tsunozaki M, Rockman MV, Kruglyak L and Bargmann CI (2011) Catecholamine receptor polymorphisms affect decision-making in C. elegans. Nature 472, 313-318.

Bensafi M, Frasnelli J, Reden J and Hummel T (2007) The neural representation of odor is modulated by the presence of a trigeminal stimulus during odor encoding. Clinical Neurophysiology 118, 696-701.

Bernard GC, Egnin M and Bonsi C (2017) The impact of plant-parasitic nematodes on agriculture and methods of control. In Shah MM and Mahamood M (eds), Nematology: Concepts, Control, and Diagnosis. London, UK: IntechOpen, pp. 121-151. doi: 10.5772/intechopen.68958.

Bezubik B (1965) Failure to establish infection in rats and guinea pigs exposed to the larvae of Strongyloides papillosus. Acta Parasitologica 13, 349-354.

Bhattacharya A, Aghayeva U, Berghoff EG and Hobert O (2019) Plasticity of the electrical connectome of C. elegans. Cell 176, 1174-1189.

Bhopale VM, Kupprion EK, Ashton FT, Boston R and Schad GA (2001) Ancylostoma caninum: the finger cell neurons mediate thermotactic behavior by infective larvae of the dog hookworm. Experimental Parasitology 97, 70-76.

Blaxter M and Koutsovoulos G (2015) The evolution of parasitism in Nematoda. Parasitology 142(suppl. 1), S26-S39.

Blaxter M, Koutsovoulos G, Jones M, Kumar S and Elsworth B (2016) Phylogenomics of Nematoda. In Olson PD, Hughes J and Cotton JA (eds), Next Generation Systematics. Cambridge, UK: Cambridge University Press, pp. 62-82.

Boatin BA, Basanez MG, Prichard RK, Awadzi K, Barakat RM, Garcia HH, Gazzinelli A, Grant WN, McCarthy JS, N'Goran EK, OseiAtweneboana MY, Sripa B, Yang GJ and Lustigman S (2012) A research agenda for helminth diseases of humans: towards control and elimination. PLoS Neglected Tropical Diseases 6, e1547.

Brandt JP and Ringstad N (2015) Toll-like receptor signaling promotes development and function of sensory neurons required for a C. elegans pathogen-avoidance behavior. Current Biology 25, 2228-2237.

Brandt JP, Aziz-Zaman S, Juozaityte V, Martinez-Velazquez LA, Petersen JG, Pocock R and Ringstad N (2012) A single gene target of an ETS-family transcription factor determines neuronal $\mathrm{CO}_{2}$-chemosensitivity. PLoS ONE 7, e34014.

Bretscher AJ, Busch KE and de Bono M (2008) A carbon dioxide avoidance behavior is integrated with responses to ambient oxygen and food in Caenorhabditis elegans. Proceedings of the National Academy of Sciences USA 105, 8044-8049.

Bretscher AJ, Kodama-Namba E, Busch KE, Murphy RJ, Soltesz Z, Laurent $\mathbf{P}$ and de Bono $\mathbf{M}$ (2011) Temperature, oxygen, and salt-sensing 
neurons in C. elegans are carbon dioxide sensors that control avoidance behavior. Neuron 69, 1099-1113.

Brindley PJ, Mitreva M, Ghedin E and Lustigman S (2009) Helminth genomics: the implications for human health. PLoS Neglected Tropical Diseases 3, e538.

Britton C, Samarasinghe B and Knox DP (2012) Ups and downs of RNA interference in parasitic nematodes. Experimental Parasitology 132, 56-61.

Bryant AS and Hallem EA (2018) Terror in the dirt: sensory determinants of host seeking in soil-transmitted mammalian-parasitic nematodes. International Journal for Parasitology: Drugs and Drug Resistance 8, 496-510.

Bryant AS, Ruiz F, Gang SS, Castelletto ML, Lopez JB and Hallem EA (2018) A critical role for thermosensation in host seeking by skinpenetrating nematodes. Current Biology 28, 2338-2347.

Bumbarger DJ, Crum J, Ellisman MH and Baldwin JG (2007) Three-dimensional fine structural reconstruction of the nose sensory structures of Acrobeles complexus compared to Caenorhabditis elegans (Nematoda: rhabditida). Journal of Morphology 268, 649-663.

Bumbarger DJ, Wijeratne S, Carter C, Crum J, Ellisman MH and Baldwin JG (2009) Three-dimensional reconstruction of the amphid sensilla in the microbial feeding nematode, Acrobeles complexus (Nematoda: rhabditida). Journal of Comparative Neurology 512, 271-281.

Burg SP and Burg EA (1965) Gas exchange in fruits. Physiologia Plantarum 18, 870-884.

Buszewski B, Kesy M, Ligor T and Amann A (2007) Human exhaled air analytics: biomarkers of diseases. Biomedical Chromatography 21, 553-566.

Byrnes CA, Dinarevic S, Shinebourne EA, Barnes PJ and Bush A (1997) Exhaled nitric oxide measurements in normal and asthmatic children. Pediatric Pulmonology 24, 312-318.

Campbell JF and Gauger R (1993) Nictation behaviour and its ecological implications in the host search strategies of entomopathogenic nematodes (Heterorhabditidae and Steinernematidae). Behaviour 126, 155-169.

Campbell JF and Kaya HK (1999) How and why a parasitic nematode jumps. Nature 397, 485-486

Campbell JF and Kaya HK (2000) Influence of insect-associated cues on the jumping behavior of entomopathogenic nematodes (Steinernema spp.) Behaviour 137, 591-609.

Carrillo MA and Hallem EA (2015) Gas sensing in nematodes. Molecular Neurobiology 51, 919-931.

Carrillo MA, Guillermin ML, Rengarajan S, Okubo $R$ and Hallem EA (2013) $\mathrm{O}_{2}$-sensing neurons control $\mathrm{CO}_{2}$ response in C. elegans. Journal of Neuroscience 33, 9675-9683.

Castelletto ML, Gang SS, Okubo RP, Tselikova AA, Nolan TJ, Platzer EG, Lok JB and Hallem EA (2014) Diverse host-seeking behaviors of skinpenetrating nematodes. PLoS Pathogens 10, e1004305.

Caswell-Chen EP, Chen J, Lewis EE, Douhan GW, Nadler SA and Carey JR (2005) Revising the standard wisdom of C. elegans natural history: ecology of longevity. Science of Aging Knowledge Environment 2005, pe30.

Chang DZ, Serra L, Lu D, Mortazavi A and Dillman AR (2019) A core set of venom proteins is released by entomopathogenic nematodes in the genus Steinernema. PLoS Pathogens 15, e1007626.

Chen TW, Wardill TJ, Sun Y, Pulver SR, Renninger SL, Baohan A, Schreiter ER, Kerr RA, Orger MB, Jayaraman V, Looger LL, Svoboda K and Kim DS (2013) Ultrasensitive fluorescent proteins for imaging neuronal activity. Nature 499, 295-300.

Crook M (2014) The dauer hypothesis and the evolution of parasitism: 20 years on and still going strong. International Journal for Parasitology 44 $1-8$.

Dana H, Mohar B, Sun Y, Narayan S, Gordus A, Hasseman JP, Tsegaye G, Holt GT, Hu A, Walpita D, Patel R, Macklin JJ, Bargmann CI, Ahrens MB, Schreiter ER, Jayaraman V, Looger LL, Svoboda $K$ and Kim DS (2016) Sensitive red protein calcium indicators for imaging neural activity. eLife 5: e12727. doi: 10.7554/eLife.12727.

Decraemer W and Hunt D (2006) Structure and classification. In Perry R and Moens M (eds), Plant Nematology. Oxfordshire: CAB International, pp. 3-32.

de Lacy Costello B, Amann A, Al-Kateb H, Flynn C, Filipiak W, Khalid T, Osborne D and Ratcliffe NM (2014) A review of the volatiles from the healthy human body. Journal of Breath Research 8, 014001.

Diawara A, Schwenkenbecher JM, Kaplan RM and Prichard RK (2013) Molecular and biological diagnostic tests for monitoring benzimidazole resistance in human soil-transmitted helminths. American Journal of Tropical Medicine and Hygiene 88, 1052-1061.
Dillman AR and Sternberg PW (2012) Entomopathogenic nematodes. Current Biology 22, R430-R431.

Dillman AR, Chaston JM, Adams BJ, Ciche TA, Goodrich-Blair H, Stock SP and Sternberg PW (2012a) An entomopathogenic nematode by any other name. PLoS Pathogens 8, e1002527.

Dillman AR, Guillermin ML, Lee JH, Kim B, Sternberg PW and Hallem EA (2012b) Olfaction shapes host-parasite interactions in parasitic nematodes. Proceedings of the National Academy of Sciences USA 109, E2324-E2333.

Dold C and Holland CV (2011) Ascaris and ascariasis. Microbes and Infections 13, 632-637.

Douvres FW and Urban JF (1983) Factors contributing to the in vitro development of Ascaris suum from second-stage larvae to mature adults. Journal of Parasitology 69, 549-558.

Drexel T, Mahofsky K, Latham R, Zimmer M and Cochella L (2016) Neuron type-specific miRNA represses two broadly expressed genes to modulate an avoidance behavior in C. elegans. Genes and Development 30, 2042-2047.

Dulovic A and Streit A (2019) RNAi-mediated knockdown of daf-12 in the model parasitic nematode Strongyloides ratti. PLoS Pathogens 15, e1007705.

Dusenbery DB (1985) Video camera-computer tracking of nematode Caenorhabditis elegans to record behavioral responses. Journal of Chemical Ecology 11, 1239-1247.

Emery DL, Hunt PW and Le Jambre LF (2016) Haemonchus contortus: the then and now, and where to from here? International Journal for Parasitology 46, 755-769.

Evans TC (2006) Transformation and microinjection. In The C. elegans Research Community (eds). WormBook, pp. 1-15. http://www.wormbook. org.

Fairbairn D (1961) The in vitro hatching of Ascaris lumbricoides eggs. Canadian Journal of Zoology 39, 153-162.

Felix MA and Braendle C (2010) The natural history of Caenorhabditis elegans. Current Biology 20, R965-R969.

Felix MA and Duveau F (2012) Population dynamics and habitat sharing of natural populations of Caenorhabditis elegans and C. briggsae. BMC Biology 10, 59.

Fenk LA and de Bono M (2015) Environmental $\mathrm{CO}_{2}$ inhibits Caenorhabditis elegans egg-laying by modulating olfactory neurons and evokes widespread changes in neural activity. Proceedings of the National Academy of Sciences USA 112, E3525-E3534.

Fenk LA and de Bono M (2017) Memory of recent oxygen experience switches pheromone valence in Caenorhabditis elegans. Proceedings of the National Academy of Sciences USA 114, 4195-4200.

Forbes WM, Ashton FT, Boston R, Zhu X and Schad GA (2004) Chemoattraction and chemorepulsion of Strongyloides stercoralis infective larvae on a sodium chloride gradient is mediated by amphidial neuron pairs ASE and ASH, respectively. Veterinary Parasitology 120, 189-198.

Gang SS and Hallem EA (2016) Mechanisms of host seeking by parasitic nematodes. Molecular and Biochemical Parasitology 208, 23-32.

Gang SS, Castelletto ML, Bryant AS, Yang E, Mancuso N, Lopez JB, Pellegrini M and Hallem EA (2017) Targeted mutagenesis in a humanparasitic nematode. PLoS Pathogens 13, e1006675.

Gaugler R, LeBeck L, Nakagaki B and Boush GM (1980) Orientation of the entomogenous nematode Neoaplectana carpocapsae to carbon dioxide. Environmental Entomology 9, 649-652.

Gaugler R, Campbell JF and Gupta P (1991) Characterization and basis of enhanced host-finding in a genetically improved strain of Steinernema carpocapsae. Journal of Invertebrate Pathology 57, 234-241.

Geldhof P, Murray L, Couthier A, Gilleard JS, McLauchlan G, Knox DP and Britton C (2006) Testing the efficacy of RNA interference in Haemonchus contortus. International Journal for Parasitology 36, 801-810.

Granzer M and Haas W (1991) Host-finding and host recognition of infective Ancylostoma caninum larvae. International Journal for Parasitology 21, 429-440.

Gray JM, Karow DS, Lu H, Chang AJ, Chang JS, Ellis RE, Marletta MA and Bargmann CI (2004) Oxygen sensation and social feeding mediated by a $C$. elegans guanylate cyclase homologue. Nature 430, 317-322.

Grewal PS, Ehlers R-U and Shapiro-Ilan DI (2005) Nematodes as Biocontrol Agents. Cambridge: CABI Publishing.

Guillermin ML, Castelletto ML and Hallem EA (2011) Differentiation of carbon dioxide-sensing neurons in Caenorhabditis elegans requires the ETS-5 transcription factor. Genetics 189, 1327-1339.

Guillermin ML, Carrillo MA and Hallem EA (2017) A single set of interneurons drives opposite behaviors in C. elegans. Current Biology 27, 2630-2639. 
Guo L, Chang Z, Dieterich C and Streit A (2015) A protocol for chemical mutagenesis in Strongyloides ratti. Experimental Parasitology 158, 2-7.

Haas W, Haberl B, Idris SI, Kallert D, Kersten S and Stiegeler P (2005) Behavioural strategies used by the hookworms Necator americanus and Ancylostoma duodenale to find, recognize and invade the human host. Parasitology Research 95, 30-39.

Haley AJ (1961) Biology of the rat nematode Nippostrongylus brasiliensis (Travassos, 1914). I. Systematics, hosts and geographic distribution. Journal of Parasitology 47, 727-732.

Hallem EA and Sternberg PW (2008) Acute carbon dioxide avoidance in Caenorhabditis elegans. Proceedings of the National Academy of Sciences USA 105, 8038-8043.

Hallem EA, Dillman AR, Hong AV, Zhang Y, Yano JM, DeMarco SF and Sternberg PW (2011a) A sensory code for host seeking in parasitic nematodes. Current Biology 21, 377-383.

Hallem EA, Spencer WC, McWhirter RD, Zeller G, Henz SR, Ratsch G, Miller DM, Horvitz HR, Sternberg PW and Ringstad N (2011b) Receptor-type guanylate cyclase is required for carbon dioxide sensation by Caenorhabditis elegans. Proceedings of the National Academy of Sciences USA 108, 254-259.

Hansen EL and Buecher EJ (1970) Biochemical approach to systematic studies with axenic nematodes. Journal of Nematology 2, 1-6.

Harris G, Shen Y, Ha H, Donato A, Wallis S, Zhang X and Zhang Y (2014) Dissecting the signaling mechanisms underlying recognition and preference of food odors. Journal of Neuroscience 34, 9389-9403.

Hawdon JM and Schad GA (1990) Serum-stimulated feeding in vitro by third-stage infective larvae of the canine hookworm Ancylostoma caninum. Journal of Parasitology 76, 394-398.

Hawdon JM and Schad GA (1992) Ancylostoma caninum: reduced glutathione stimulates feeding by third-stage infective larvae. Experimental Parasitology 75, 40-46.

Hawdon JM, Volk SW, Pritchard DI and Schad GA (1992) Resumption of feeding in vitro by hookworm third-stage larvae: a comparative study. Journal of Parasitology 78, 1036-1040.

Hernandez AD and Sukhdeo MVK (1995) Host grooming and the transmission strategy of Heligmosomoides polygyrus. Journal of Parasitology 81, 865869.

Hominick WM (2002) Biogeography. In Gaugler R (ed.), Entomopathogenic Nematology. New York: CABI Publishing, pp. 115-143.

Hotez P, Hawdon J and Schad GA (1993) Hookworm larval infectivity, arrest and amphiparatenesis: the Caenorhabditis elegans Daf-c paradigm. Parasitology Today 9, 23-26.

Howe KL, Bolt BJ, Shafie M, Kersey P and Berriman M (2017) Wormbase ParaSite - a comprehensive resource for helminth genomics. Molecular and Biochemical Parasitology 215, 2-10.

Hu PJ (2007) Dauer. In The C. elegans Research Community (eds). WormBook, pp. 1-19. http://www.wormbook.org.

Hunt VL, Tsai IJ, Coghlan A, Reid AJ, Holroyd N, Foth BJ, Tracey A, Cotton JA, Stanley EJ, Beasley H, Bennett HM, Brooks K, Harsha B, Kajitani R, Kulkarni A, Harbecke D, Nagayasu E, Nichol S, Ogura Y, Quail MA, Randle N, Xia D, Brattig NW, Soblik H, Ribeiro DM, Sanchez-Flores A, Hayashi T, Itoh T, Denver DR, Grant W, Stoltzfus JD, Lok JB, Murayama H, Wastling J, Streit A, Kikuchi T, Viney $\mathbf{M}$ and Berriman $\mathbf{M}$ (2016) The genomic basis of parasitism in the Strongyloides clade of nematodes. Nature Genetics 48, 299-307.

International Helminth Genomes C (2019) Comparative genomics of the major parasitic worms. Nature Genetics 51, 163-174.

Jasmer DP, Goverse A and Smant G (2003) Parasitic nematode interactions with mammals and plants. Annual Review of Phytopathology 41, 245-270.

Jensen BB and Jorgensen H (1994) Effect of dietary fiber on microbial activity and microbial gas production in various regions of the gastrointestinal tract of pigs. Applied and Environmental Microbiology 60, 1897-1904.

Jex AR, Gasser RB and Schwarz EM (2019) Transcriptomic resources for parasitic nematodes of veterinary importance. Trends in Parasitology 35, $72-84$.

Johnson RN and Viglierchio DR (1961) The accumulation of plant parasitic nematode larvae around carbon dioxide and oxygen. Proceedings of the Helminthological Society of Washington 28, 171-174.

Junio AB, Li X, Massey Jr HC, Nolan TJ, Todd Lamitina S, Sundaram MV and Lok JB (2008) Strongyloides stercoralis: cell- and tissue-specific transgene expression and co-transformation with vector constructs incorporating a common multifunctional 3' UTR. Experimental Parasitology 118, 253-265.
Juozaityte V, Pladevall-Morera D, Podolska A, Norgaard S, Neumann B and Pocock R (2017) The ETS-5 transcription factor regulates activity states in Caenorhabditis elegans by controlling satiety. Proceedings of the National Academy of Sciences USA 114, E1651-E1658.

Kang S and Hong YS (2008) RNA interference in infectious tropical diseases. Korean Journal of Parasitology 46, 1-15.

Kaya HK and Gaugler R (1993) Entomopathogenic nematodes. Annual Review of Entomology 38, 181-206.

Keiser J and Utzinger J (2008) Efficacy of current drugs against soiltransmitted helminth infections: systematic review and meta-analysis. Journal of the American Medical Association 299, 1937-1948.

Ketschek AR, Joseph R, Boston R, Ashton FT and Schad GA (2004) Amphidial neurons ADL and ASH initiate sodium dodecyl sulphate avoidance responses in the infective larva of the dog hookworm Anclyostoma caninum. International Journal for Parasitology 34, 1333-1336.

Klingler J (1972) The effect of single and combined heat and $\mathrm{CO}_{2}$ stimuli at different ambient temperatures on the behavior of two plant-parasitic nematodes. Journal of Nematology 4, 95-100.

Kodama-Namba E, Fenk LA, Bretscher AJ, Gross E, Busch KE and de Bono M (2013) Cross-modulation of homeostatic responses to temperature, oxygen and carbon dioxide in C. elegans. PLoS Genetics 9, e1004011.

Kotze AC and Bagnall NH (2006) RNA interference in Haemonchus contortus: suppression of b-tubulin gene expression in L3, L4 and adult worms in vitro. Molecular and Biochemical Parasitology 145, 101-110.

Kumar N, Rao TK, Varghese A and Rathor VS (2013) Internal parasite management in grazing livestock. Journal of Parasitic Diseases 37, 151-157.

Labaude S and Griffin CT (2018) Transmission success of entomopathogenic nematodes used in pest control. Insects 9,72 .

Lahiri S and Forster II RE (2003) $\mathrm{CO}_{2} / \mathrm{H}^{+}$sensing: peripheral and central chemoreception. International Journal of Biochemistry and Cell Biology 35, 1413-1435.

Laing R, Kikuchi T, Martinelli A, Tsai IJ, Beech RN, Redman E, Holroyd N, Bartley DJ, Beasley H, Britton C, Curran D, Devaney E, Gilabert A, Hunt M, Jackson F, Johnston SL, Kryukov I, Li K, Morrison AA, Reid AJ, Sargison N, Saunders GI, Wasmuth JD, Wolstenholme A, Berriman M, Gilleard JS and Cotton JA (2013) The genome and transcriptome of Haemonchus contortus, a key model parasite for drug and vaccine discovery. Genome Biology 14, R88.

Learmount J, Stephens N, Boughtflower V, Barrecheguren A and Rickell K (2016) The development of anthelmintic resistance with best practice control of nematodes on commercial sheep farms in the UK. Veterinary Parasitology 229, 9-14.

Lee H, Choi MK, Lee D, Kim HS, Hwang H, Kim H, Park S, Paik YK and Lee J (2012) Nictation, a dispersal behavior of the nematode Caenorhabditis elegans, is regulated by IL2 neurons. Nature Neuroscience 15, 107-112.

Lee J, Dillman AR and Hallem EA (2016) Temperature-dependent changes in the host-seeking behaviors of parasitic nematodes. BMC Biology 14, 36.

Lee JS, Shih PY, Schaedel ON, Quintero-Cadena P, Rogers AK and Sternberg PW (2017) FMRFamide-like peptides expand the behavioral repertoire of a densely connected nervous system. Proceedings of the National Academy of Sciences USA 114, E10726-E10735.

Lendner M, Doligalska M, Lucius R and Hartmann S (2008) Attempts to establish RNA interference in the parasitic nematode Heligmosomoides polygyrus. Molecular and Biochemical Parasitology 161, 21-31.

Lewis EE (2002) Behavioral ecology. In Gauger R (ed.), Entomopathogenic Nematology. New York: CAB International, pp. 205-223.

Lewis EE, Gauger R and Harrison R (1993) Response of cruiser and ambusher entomopathogenic nematodes (steinernematidae) to host volatile cues. Canadian Journal of Zoology 71, 765-769.

Lewis EE, Campbell J, Griffin C, Kaya H and Peters A (2006) Behavioral ecology of entomopathogenic nematodes. Biological Control 38, 66-79.

Li J, Ashton FT, Gamble HR and Schad GA (2000a) Sensory neuroanatomy of a passively ingested nematode parasite, Haemonchus contortus: amphidial neurons of the first stage larva. Journal of Comparative Neurology 417, 299-314.

Li J, Zhu X, Boston R, Ashton FT, Gamble HR and Schad GA (2000b) Thermotaxis and thermosensory neurons in infective larvae of Haemonchus contortus, a passively ingested nematode parasite. Journal of Comparative Neurology 424, 58-73.

Li J, Zhu X, Ashton FT, Gamble HR and Schad GA (2001) Sensory neuroanatomy of a passively ingested nematode parasite, Haemonchus contortus: amphidial neurons of the third-stage larva. Journal of Parasitology 87, 65-72. 
Li X, Massey Jr HC, Nolan TJ, Schad GA, Kraus K, Sundaram M and Lok JB (2006) Successful transgenesis of the parasitic nematode Strongyloides stercoralis requires endogenous non-coding control elements. International Journal for Parasitology 36, 671-679.

Li X, Shao H, Junio A, Nolan TJ, Massey Jr HC, Pearce EJ, Viney ME and Lok JB (2011) Transgenesis in the parasitic nematode Strongyloides ratti. Molecular and Biochemical Parasitology 179, 114-119.

Liu T and Cai D (2013) Counterbalance between BAG and URX neurons via guanylate cyclases controls lifespan homeostasis in C. elegans. EMBO Journal 32, 1529-1542.

Liu J, Poinar Jr GO and Berry RE (2000) Control of insect pests with entomopathogenic nematodes: the impact of molecular biology and phylogenetic reconstruction. Annual Review of Entomology 45, 287-306.

Lok JB (2007) Strongyloides stercoralis: a model for translational research on parasitic nematode biology. In The C. elegans Research Community (eds). WormBook, pp. 1-18. http://www.wormbook.org.

Lok J (2013) Piggybac: a vehicle for integrative DNA transformation of parasitic nematodes. Mobile Genetic Elements 3, e24417.

Lok JB (2012) Nucleic acid transfection and transgenesis in parasitic nematodes. Parasitology 139, 574-588.

Lok JB and Artis D (2008) Transgenesis and neuronal ablation in parasitic nematodes: revolutionary new tools to dissect host-parasite interactions. Parasite Immunology 30, 203-214.

Lok JB and Massey Jr HC (2002) Transgene expression in Strongyloides stercoralis following gonadal microinjection of DNA constructs. Molecular and Biochemical Parasitology 119, 279-284.

Lok JB, Shao H, Massey HC and Li X (2017) Transgenesis in Strongyloides and related parasitic nematodes: historical perspectives, current functional genomic applications and progress towards gene disruption and editing. Parasitology 144, 327-342.

Lopez PM, Boston R, Ashton FT and Schad GA (2000) The neurons of class ALD mediate thermotaxis in the parasitic nematode, Strongyloides stercoralis. International Journal for Parasitology 30, 1115-1121.

Lu D, Macchietto M, Chang D, Barros MM, Baldwin J, Mortazavi A and Dillman AR (2017) Activated entomopathogenic nematode infective juveniles release lethal venom proteins. PLoS Pathogens 13, e1006302.

Lustigman S, Prichard RK, Gazzinelli A, Grant WN, Boatin BA, McCarthy JS and Basanez MG (2012) A research agenda for helminth diseases of humans: the problem of helminthiases. PLoS Neglected Tropical Diseases 6, e1582.

McCallum ME and Dusenbery DB (1992) Computer tracking as a behavioral GC detector: nematode responses to vapor of host roots. Journal of Chemical Ecology 18, 585-592.

McGrath PT, Rockman MV, Zimmer M, Jang H, Macosko EZ, Kruglyak L and Bargmann CI (2009) Quantitative mapping of a digenic behavioral trait implicates globin variation in C. elegans sensory behaviors. Neuron 61, 692-699.

Milward K, Busch KE, Murphy RJ, de Bono M and Olofsson B (2011) Neuronal and molecular substrates for optimal foraging in Caenorhabditis elegans. Proceedings of the National Academy of Sciences USA 108, 20672-20677.

Mitreva M, Zarlenga DS, McCarter JP and Jasmer DP (2007) Parasitic nematodes - from genomes to control. Veterinary Parasitology 148, 31-42.

Nagai T, Yamada S, Tominaga T, Ichikawa M and Miyawaki A (2004) Expanded dynamic range of fluorescent indicators for $\mathrm{Ca}^{2+}$ by circularly permuted yellow fluorescent proteins. Proceedings of the National Academy of Sciences USA 101, 10554-10559.

Nguyen KB and Hunt DJ eds (2007) Entomopathogenic Nematodes: Systematics, Phylogeny and Bacterial Symbionts. Leiden, The Netherlands: Brill.

Nguyen KB and Smart GC (1991) Pathogenicity of Steinernema scapterisci to selected invertebrate hosts. Journal of Nematology 23, 7-11.

Nolan TJ, Brenes M, Ashton FT, Zhu X, Forbes WM, Boston R and Schad GA (2004) The amphidial neuron pair ALD controls the temperature-sensitive choice of alternative developmental pathways in the parasitic nematode, Strongyloides stercoralis. Parasitology 129, 753-759.

Nolan TJ, Zhu X, Ketschek A, Cole J, Grant W, Lok JB and Schad GA (2007) The sugar glider (Petaurus breviceps): a laboratory host for the nematode Parastrongyloides trichosuri. Journal of Parasitology 93, 10841089 .

Nutman TB (2017) Human infection with Strongyloides stercoralis and other related Strongyloides species. Parasitology 144, 263-273.
O'Connor LJ, Walkden-Brown SW and Kahn LP (2006) Ecology of the freeliving stages of major trichostrongylid parasites of sheep. Veterinary Parasitology 142, 1-15.

O'Halloran DM and Burnell AM (2003) An investigation of chemotaxis in the insect parasitic nematode Heterorhabditis bacteriophora. Parasitology 127, 375-385.

Page W, Judd JA and Bradbury RS (2018) The unique life cycle of Strongyloides stercoralis and implications for public health action. Tropical Medicine and Infectious Disease 3, 53.

Peters A (1996) The natural host range of Steinernema and Heterorhabditis spp. and their impact on insect populations. Biocontrol Science and Technology 6, 389-402.

Petersen JG, Romanos TR, Juozaityte V, Riveiro AR, Hum I, Traunmuller L, Zimmer M and Pocock R (2013) EGL-13/SoxD specifies distinct $\mathrm{O}_{2}$ and $\mathrm{CO}_{2}$ sensory neuron fates in Caenorhabditis elegans. PLoS Genetics 9, e1003511.

Pilz M and Hohberg K (2015) Laboratory experiments on nematodes from natural $\mathrm{CO}_{2}$ springs reveal species-specific tolerance to extreme $\mathrm{CO}_{2}$ concentrations. Soil Biology and Biochemistry 88, 165-168.

Pokala N, Liu Q, Gordus A and Bargmann CI (2014) Inducible and titratable silencing of Caenorhabditis elegans neurons in vivo with histamine-gated chloride channels. Proceedings of the National Academy of Sciences USA 111, 2770-2775.

Prichard RK, Basanez MG, Boatin BA, McCarthy JS, Garcia HH, Yang GJ, Sripa B and Lustigman S (2012) A research agenda for helminth diseases of humans: intervention for control and elimination. PLoS Neglected Tropical Diseases 6, e1549.

Prot JC (1980) Migration of plant-parasitic nematodes towards plant roots. Revue de Nematology 3, 305-318.

Pye AE and Burman M (1981) Neoaplectana carpocapsae: nematode accumulations on chemical and bacterial gradients. Experimental Parasitology 51, 13-20.

Qi YB, Garren EJ, Shu X, Tsien RY and Jin Y (2012) Photo-inducible cell ablation in Caenorhabditis elegans using the genetically encoded singlet oxygen generating protein miniSOG. Proceedings of the National Academy of Sciences of the USA 109, 7499-7504.

Rengarajan S, Yankura KA, Guillermin ML, Fung W and Hallem EA (2019) Feeding state sculpts a circuit for sensory valence in Caenorhabditis elegans. Proceedings of the National Academy of Sciences of the USA 116, 1776-1781.

Repetto SA, Ruybal P, Batalla E, Lopez C, Fridman V, Sierra M, Radisic M, Bravo PM, Risso MG, Gonzalez Cappa SM and Alba Soto CD (2018) Strongyloidiasis outside endemic areas: long-term parasitological and clinical follow-up after ivermectin treatment. Journal of Biochemistry and Molecular Biology 66, 1558-1565.

Riemann F and Schrage M (1988) Carbon dioxide as an attractant for the free-living marine nematode Adoncholaimus thalassophygas. Marine Biology 98, 81-85.

Roberts LS, Janovy J and Schmidt P (2005) Foundations of Parasitology, 7th Edn. New York City, USA: McGraw-Hill.

Robinson AF (1995) Optimal release rates for attracting Meloidogyne incognita, Rotylenchulus reniformis, and other nematodes to carbon dioxide in sand. Journal of Nematology 27, 42-50.

Roeber F, Jex AR and Gasser RB (2013) Impact of gastrointestinal parasitic nematodes of sheep, and the role of advanced molecular tools for exploring epidemiology and drug resistance - an Australian perspective. Parasites \& Vectors 6, 153.

Rogers WP and Sommerville RI (1960) The physiology of the second ecdysis of parasitic nematodes. Parasitology 50, 329-348.

Rojo Romanos T, Petersen JG and Pocock R (2017) Control of neuropeptide expression by parallel activity-dependent pathways in Caenorhabditis elegans. Scientific Reports 7, 38734.

Rotbart A, Yao CK, Ha N, Chrispa MD, Muir JG, Gibson PR, Kalantar-Zadeh K and Ou JZ (2017) Designing an in-vitro gas profiling system for human faecal samples. Sensors and Actuators. B, Chemical 238, 754-764

Ruiz F, Castelletto ML, Gang SS and Hallem EA (2017) Experiencedependent olfactory behaviors of the parasitic nematode Heligmosomoides polygyrus. PLoS Pathogens 13, e1006709.

Samarasinghe B, Knox DP and Britton C (2011) Factors affecting susceptibility to RNA interference in Haemonchus contortus and in vivo silencing of an H11 aminopeptidase gene. International Journal for Parasitology 41, $51-59$. 
Schiavo G, Benfenati F, Poulain B, Rossetto O, Polverino de Laureto P, DasGupta BR and Montecucco C (1992) Tetanus and botulinum-B neurotoxins block neurotransmitter release by proteolytic cleavage of synaptobrevin. Nature 359, 832-835.

Schmidt J and All JN (1979) Attraction of Neoaplectana carpocapsae (Nematoda: Steinernematidae) to common excretory products of insects. Environmental Entomology 8, 55-61.

Schulenburg H and Felix MA (2017) The natural biotic environment of Caenorhabditis elegans. Genetics 206, 55-86.

Sciacca J, Forbes WM, Ashton FT, Lombardini E, Gamble HR and Schad GA (2002) Response to carbon dioxide by the infective larvae of three species of parasitic nematodes. Parasitology International 51, 53-62.

Scott K (2011) Out of thin air: sensory detection of oxygen and carbon dioxide. Neuron 69, 194-202.

Serrano-Saiz E, Poole RJ, Felton T, Zhang F, De La Cruz ED and Hobert O (2013) Modular control of glutamatergic neuronal identity in C. elegans by distinct homeodomain proteins. Cell 155, 659-673.

Shao H, Li X, Nolan TJ, Massey Jr HC, Pearce EJ and Lok JB (2012) Transposon-mediated chromosomal integration of transgenes in the parasitic nematode Strongyloides ratti and establishment of stable transgenic lines. PLoS Pathogens 8, e1002871.

Shao HG, Li XS and Lok JB (2017) Heritable genetic transformation of Strongyloides stercoralis by microinjection of plasmid DNA constructs into the male germline. International Journal for Parasitology 47, 511-515.

Sharabi K, Hurwitz A, Simon AJ, Beitel GJ, Morimoto RI, Rechavi G, Sznajder JI and Gruenbaum Y (2009) Elevated $\mathrm{CO}_{2}$ levels affect development, motility, and fertility and extend life span in Caenorhabditis elegans. Proceedings of the National Academy of Sciences USA 106, 4024-4029.

Shusterman D and Avila PC (2003) Real-time monitoring of nasal mucosal $\mathrm{pH}$ during carbon dioxide stimulation: implications for stimulus dynamics. Chemical Senses 28, 595-601.

Smallegange RC, Verhulst NO and Takken W (2011) Sweaty skin: an invitation to bite? Trends in Parasitology 27, 143-148.

Smith ES, Martinez-Velazquez L and Ringstad N (2013) A chemoreceptor that detects molecular carbon dioxide. Journal of Biological Chemistry 288, 37071-37081.

Sommerville RI (1964) Effect of carbon dioxide on the development of thirdstage larvae of Haemonchus contortus in vitro. Nature 202, 316-317.

Srinivasan J, Durak O and Sternberg PW (2008) Evolution of a polymodal sensory response network. BMC Biology 6, 52.

Stoltzfus JD, Massey Jr HC, Nolan TJ, Griffith SD and Lok JB (2012) Strongyloides stercoralis age-1: a potential regulator of infective larval development in a parasitic nematode. PLoS ONE 7, e38587.

Stoltzfus JD, Bart SM and Lok JB (2014) cGMP and NHR signaling co-regulate expression of insulin-like peptides and developmental activation of infective larvae in Strongyloides stercoralis. PLoS Pathogens 10, e1004235.

Taylor KA and Weinstein PP (1990) The effect of oxygen and carbon dioxide on the development of the free-living stages of Strongyloides ratti in axenic culture. Journal of Parasitology 76, 545-551.

Taylor A and Whitlock JH (1960) The exsheathing stimulus for infective larvae of Haemonchus contortus. Cornell Veterinarian 50, 339-344.

Turlings TC, Hiltpold I and Rasmann S (2012) The importance of rootproduced volatiles as foraging cues for entomopathogenic nematodes. Plant and Soil 358, 51-60.
Tzelos T (2014) RNA interference in parasitic nematodes - from genome to control (PhD thesis). University of Edinburgh, Edinburgh, UK.

Vadasz I, Dada LA, Briva A, Helenius IT, Sharabi K, Welch LC, Kelly AM, Grzesik BA, Budinger GR, Liu J, Seeger W, Beitel GJ, Gruenbaum Y and Sznajder JI (2012) Evolutionary conserved role of c-Jun-N-terminal kinase in $\mathrm{CO}_{2}$-induced epithelial dysfunction. PLoS ONE 7, e46696.

Velikkakam T, Fiuza JA and Gaze ST (2017) Overview of hookworm infection in humans. In Singh SK (ed.), Neglected Tropical Diseases - South Asia. Cham, Switzerland: Springer International Publishing, pp. 121-135.

Viglierchio DR (1990) Carbon dioxide sensing by Panagrellus silusiae and Ditylenchus dipsaci. Revue de Nématologie 13, 425-432.

Viney ME (1999) Exploiting the life cycle of Strongyloides ratti. Parasitology Today 15, 231-235.

Viney ME (2006) The biology and genomics of Strongyloides. Medical Microbiology and Immunology 195, 49-54.

Viney M and Kikuchi T (2017) Strongyloides ratti and S. venezuelensis rodent models of Strongyloides infection. Parasitology 144, 285-294.

Viney ME and Lok JB (2007) Strongyloides spp. In The C. elegans Research Community (eds). WormBook, pp. 1-15. http://www.wormbook.org.

Viney ME and Thompson FJ (2008) Two hypotheses to explain why RNA interference does not work in animal parasitic nematodes. International Journal for Parasitology 38, 43-47.

Viney ME, Green LD, Brooks JA and Grant WN (2002) Chemical mutagenesis of the parasitic nematode Strongyloides ratti to isolate ivermectin resistant mutants. International Journal for Parasitology 32, 1677-1682.

Viney ME, Thompson FJ and Crook M (2005) TGF- $\beta$ and the evolution of nematode parasitism. International Journal for Parasitology 35, 1473-1475.

Visser A, Geldhof P, de Maere V, Knox DP, Vercruysse J and Claerebout E (2006) Efficacy and specificity of RNA interference in larval life-stages of Ostertagia ostertagi. Parasitology 133, 777-783.

Wang C, Bruening G and Williamson VM (2009) Determination of preferred $\mathrm{pH}$ for root-knot nematode aggregation using pluronic F-127 gel. Journal of Chemical Ecology 35, 1242-1251.

Williams DC, Bejjani RE, Ramirez PM, Coakley S, Kim SA, Lee H, Wen Q, Samuel A, Lu H, Hilliard MA and Hammarlund M (2013) Rapid and permanent neuronal inactivation in vivo via subcellular generation of reactive oxygen with the use of KillerRed. Cell Reports 5, 553-563.

Wrather JA, Koenning SR and Anderson TR (2003) Effect of diseases on soybean yields in the United States and Ontario (1999-2002). Plant Health Progress. doi: 10.1094/PHP-2003-0325-01-RV.

Wu Y, Wickham JD, Zhao L and Sun J (2019) $\mathrm{CO}_{2}$ drives the pine wood nematode off its insect vector. Current Biology 29, R619-R620.

Zawadzki JL, Kotze AC, Fritz JA, Johnson NM, Hemsworth JE, Hines BM and Behm CA (2012) Silencing of essential genes by RNA interference in Haemonchus contortus. Parasitology 139, 613-629.

Zhu H, Li J, Nolan TJ, Schad GA and Lok JB (2011) Sensory neuroanatomy of Parastrongyloides trichosuri, a nematode parasite of mammals: amphidial neurons of the first-stage larva. Journal of Comparative Neurology 519, 2493-2507.

Zimmer M, Gray JM, Pokala N, Chang AJ, Karow DS, Marletta MA, Hudson ML, Morton DB, Chronis N and Bargmann CI (2009) Neurons detect increases and decreases in oxygen levels using distinct guanylate cyclases. Neuron 61, 865-879. 